УДК $553.24(571.65)$

\title{
О СУЛЬФИДНОЙ МИНЕРАЛИЗАЦИИ ЗОН КРУПНЫХ РАЗЛОМОВ ЯНО-КОЛЫМСКОГО ОРОГЕННОГО ПОЯСА
}

\author{
Н. А. Горячев ${ }^{1}$, О. Т. Соцкая ${ }^{1}$ А. В. Игнатьев ${ }^{2}$ Т. И. Веливецкая ${ }^{2}$ Е. М. Горячева \\ Ф. И. Семышев ${ }^{1}$, Н. В. Бердников ${ }^{3}$ М. А. Малиновский ${ }^{1}$ А. В. Альшевский ${ }^{1}$ \\ ${ }^{l}$ ФГБУН Северо-Восточный комплексный научно-исследовательский институт \\ им. Н. А. Шило ДВО РАН, г. Магадан \\ ${ }^{2}$ Дальневосточный геологический институт ДВО РАН, г. Владивосток \\ ${ }^{3}$ Институт тектоники и геофизики им. Ю. А. Косыгина ДВО РАН, г. Хабаровск \\ E-mail: goryachev@neisri.ru
}

\begin{abstract}
Изучение зон рассеянной сульфидизации Чай-Юрьинского, Дебинского и ОротуканоСреднеканского крупных разломов и прилегающих позднетриасовых и раннеюрских осадочных комплексов юго-восточного фланга Яно-Колымского орогенного пояса выявило в них не менее шести типов пирита (главный минерал), пирротин (второстепенный минерал), галенит, сфалерит, халькопирит, минералы Со и Ni. Все находки такого разнообразия сульфидных минералов характерны только для зон сульфидизации в непосредственной близости от тектонических швов. Исследование вариаций состава минералов, распределения примесей и изотопии серы позволило выделить среди пирита три генетические группы: (1) седиментогенный пирит (глобулярный и конкреционный), (2) гидротермально-метаморфогенный мелко- и крупнокристаллический пирит, иногда в ассоциации с халькопиритом и пирротином, и (3) caмый поздний мелко- и крупнокристаллический рудно-гидротермальный пирит, в ассоциации с галенитом, сфалеритом и другими рудными минералами, который определяет рудный фон зон разломов как путей миграции орогенных рудообразующих флюидов. Для зон сульфидизации отмечены повышенные содержания $\mathrm{As}, \mathrm{Ag}, \mathrm{Sb}, \mathrm{Ni}, \mathrm{Co}, \mathrm{Pb}, \mathrm{Cu}, \mathrm{Zn}$ в отдельных пробах, что обусловлено типохимизмом пирита и пирротина и присутствием собственных минералов этих элементов. Приведены первые данные об уровне концентраций элементов платиновой группы в поздних пиритах. Наши данные хорошо согласуются с моделью (Gapais et al., 2014), предполагающей двухэтапное доорогенное и орогенное происхождение флюида с формированием в ядре складчатого пояса зоны частичного плавления и зарождения флюидных потоков.
\end{abstract}

Ключевые слова: сульфиды, типоморфизм пирита, благородные металлы, изотопногеохимические исследования, зоны сульфидной вкрапленности, региональные разломы, юго-восточный фланг Яно-Колымского орогенного пояса, Северо-Восток России.

DOI: $10.34078 / 1814-0998-2020-1-11-29$

\section{ВВЕДЕНИЕ}

Орогенные складчатые пояса - это сложные зоны разнообразной складчатости, сочетающиеся со структурным каркасом из разнопорядковых разломов, определяющих контроль локализации магматических тел и металлогению орогенного пояса (Парфенов и др., 2003). Яно-Колымский орогенный пояс представляет собой деформированные позднепалеозойско-мезозойские осадочные комплексы пассивной окраины континента и прилегающих тектонических блоков иной природы, прорванные плутоническими породами раз-

(C) Горячев Н. А., Соцкая О. Т., Игнатьев А. В., Веливецкая Т. И., Горячева Е. М., Семышев Ф. И., Бердников Н. В., Малиновский М. А., Альшевский А. В., 2020 ного состава и возраста (Парфенов, 1984; Горячев, 1998, 2003; Парфенов, Кузьмин, 2001; Nokleberg et al., 2005; Геодинамика..., 2006). Структурным каркасом пояса являются крупные разломы, охарактеризованные в целом ряде сводных публикаций (Гусев, 1979; Чехов, 2000; Оксман, 2000; Парфенов, Кузьмин, 2001; Геодинамика..., 2006). Некоторые из этих разломов (Адыча-Тарынский, Чаркынский, Чай-Юрьинский, Дебинский, Оротуканский) контролируют разнообразную минерализацию, где главенствующую роль играют месторождения золота орогенного типа (Горячев, 1998, 2003; Парфенов, Кузьмин, 2001; Nokleberg et al., 2005; Геодинамика..., 2006). Однако признаков участия этого структурного каркаса в распределении золоторудной минерализации, кро- 
ме пространственной ассоциации рудных узлов, в литературе нет. Кроме того, с зонами крупных разломов часто ассоциируют обширные ареалы сульфидной пирит-пирротиновой вкрапленности, нередко с повышенными концентрациями золота. Природа такой сульфидизации представляется сложной - от осадочно-диагенетических сульфидов до гидротермально-метаморфогенных и рудных гидротермальных (Фирсов, 1963; Измайлов, 1976; Бабкин и др., 2001). Поэтому мы предприняли изучение зон сульфидной минерализации локализованных непосредственно в пределах крупных тектонических швов, к которым относятся Чай-Юрьинский, Дебинский, Оротукано-Среднеканский разломы.

Целью нашей работы является характеристика сульфидной минерализации как одного из главных минералого-геохимических признаков активной роли крупных разломов в формировании золоторудной минерализации орогенного пояса. В общие задачи исследования входило геологическое изучение данных участков по профилям вкрест простирания вмещающих структур с отбором проб для минералогического и геохимического исследования как осадочной рамы, так и самих зон разломов и сопутствующих магматических и рудных образований, а также минералого-геохимическое изучение материала отобранных проб. Основу статьи составляют наши наблюдения над сульфидной минерализацией.

Исследование проводили на аналитической базе СВКНИИ ДВО РАН (микрозондовый и электронно-микроскопический анализ, атомная абсорбция, атомно-эмисссионный спектральный анализ, минераграфические и петрографические исследования), а также в лабораториях ДВГИ ДВО РАН (стабильные изотопЫ), ХИАЦ ИТиГ ДВО РАН (ICP-MS анализ). Ссылки на примененные методики указаны в соответствующих разделах.

\section{ОБЪЕКТЫ ИССЛЕДОВАНИЯ}

Зоны региональной сульфидизации давно привлекали внимание исследователей (Измайлов, 1976; Сидоров, 1998; Бабкин и др., 2001) как возможный источник благороднометалльной минерализации. Специализированными региональноминералогическими исследованиями на СевероВостоке России были выявлены 622 протяженные зоны сульфидизации, в том числе 121 зона в ЯноКолымскои поясе, в основном пиритизации и пирротинизации (Бабкин и др., 2001). Значительная часть из них контролируется разломной тектоникой, что нашло отражение на некоторых листах Госгеолкарты-200 первого поколения (Q-55XXXI, -XXXII). Поэтому изучение сульфидной минерализации зон разломов с помощью совре- менных методов исследования необходимо для уточнения ее вклада в процессы орогенного рудообразования Яно-Колымского пояса, а также важно для оценки потенциала вкрапленных руд (Бабкин и др., 2001).

Для проведения таких исследований нами выбраны фрагменты зон Дебинско-Умарского, Чай-Юрьинского и Оротукано-Среднеканского разломов (рис. 1), для которых были высказаны предположения об их важном значении в смысле высоких перспектив продуктивности золотосульфидной минерализации (Бабкин и др., 2001). Общая характеристика разломов приведена в работах (Гусев, 1979; Чехов, 2000; Оксман, 2000; Парфенов, Кузьмин, 2001; Геодинамика..., 2006; Горячев и др., 2016).

Первый участок - «Дебинский», представляет собой зону сочленения Дебинского и его продолжения на юго-востоке Умарского разлома с Паутовским в районе Синегорья. В геологическом отношении это место сопряжения структур Иньяли-Дебинского синклинория со структурами Оротуканского поднятия (Государственная..., 2008), которое фиксируется сопряжением крупных Дебинско-Умарского и Паутовского разломов (Горячев и др., 2016). Зона сочленения разломов была пересечена в нескольких местах: (1) собственно по левобережью р. Колыма (в основном по плотикам россыпей ручьев Спокойный и Молодогвардейский; левый водораздел долины руч. Хрустальный и истоки руч. Юглер; по водораздельным хребтам притоков р. Дебин (ручьи Хрустальный и Дусканья) и в приустьевой части p. Бахапча. Также были проведены наблюдения в зоне Оротукано-Среднеканского разлома по р. Паутовая и руч. Приискатель.

Зоны разломов здесь представлены многочисленными тектоническими швами (рис. 2), разделенными блоками менее преобразованных осадочных пород. И те и другие вмещают зоны сульфидной вкрапленности и кварцевые жилы, а также единичные дайки гранит-порфиров (месторождение Юглер и др.).

Другим объектом исследований была зона Чай-Юрьинского разлома, изученная нами по плотику россыпи Чай-Юрья и бортам ее долины (Чай-Юрьинский участок), а также в бассейне ручьев Озерный (Озернинский участок) и ХараУрях (Хара-Уряхский участок) (см. рис. 1). Здесь разлом представлен отдельными ветвями, сопровождающимися зонами сульфидной вкрапленности в терригенных породах и редкими дайками среднего состава. Они в разной степени вскрыты в плотике одноименной и самой крупной россыпи мира - Чай-Юрьинской (Goryachev et al., 2020), а также в небольшой россыпи руч. Озерный и его правого притока Малый и в приустьевой части р. Хара-Урях, где она также представ- 


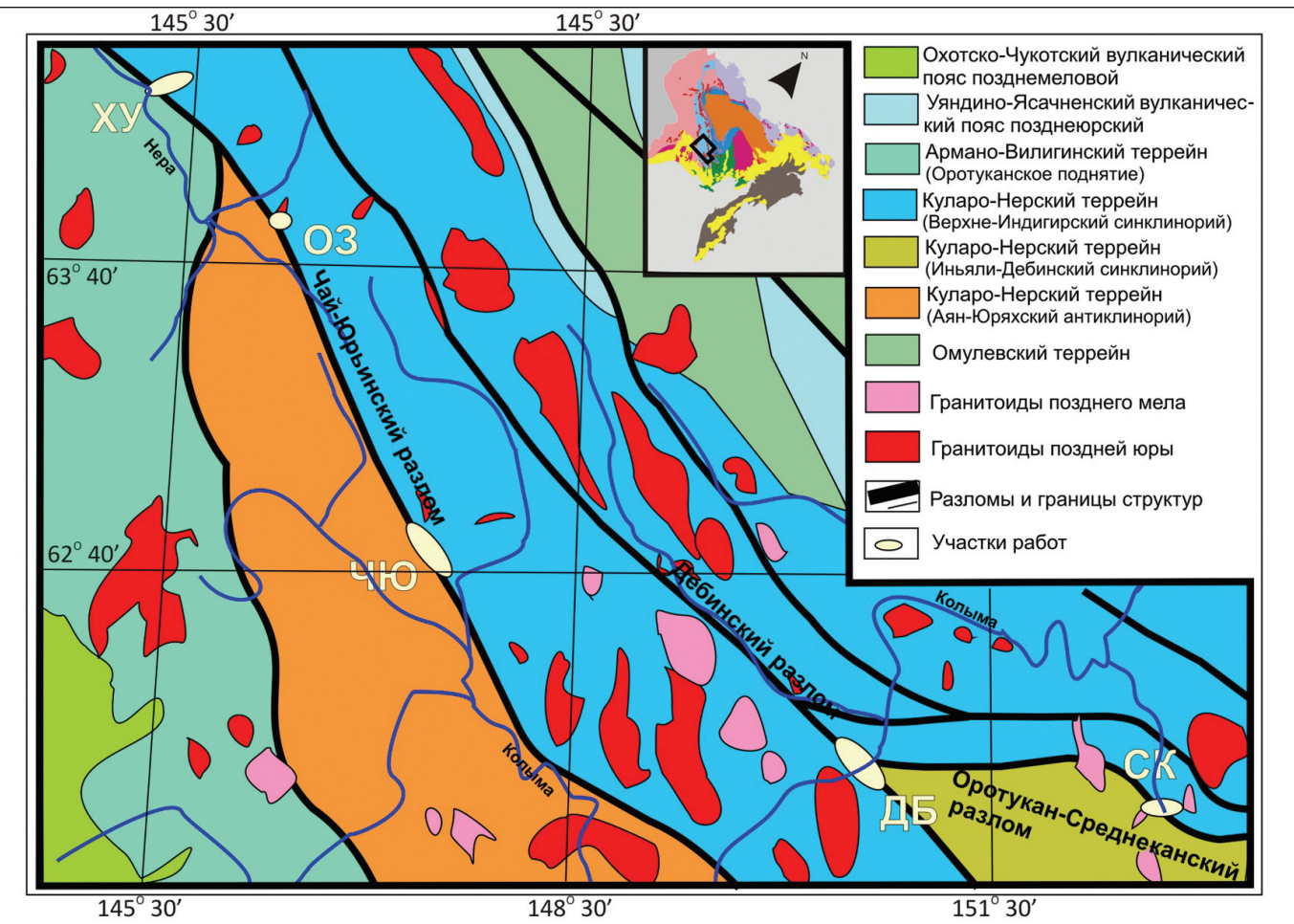

Puc. 1. Положение изученных участков в региональных структурах юго-восточного фланга Яно-Колымского пояса. Геологическая основа по карте масштаба 1:500 000 (Н. Г. Маннафов с соавторами, 1999 г.) Участки работ: ХУ «Хара-Уряхский», ОЗ - «Озернинский», ЧЮ - «Чай-Юрьинский», ДБ - «Дебинский», СК - «Среднеканский»

Fig. 1. Location of studied sites in regional structures of the southeastern flank of the Yana-Kolyma belt. Geological base by the 1:500 000 map (N. G. Mannafov et al., 1999). Work sites: XУ - Khara-Yuryakh, O3 - Ozyorninsky, ЧЮ Chay-Yurya, ДБ - Debin, СК - Srednekan
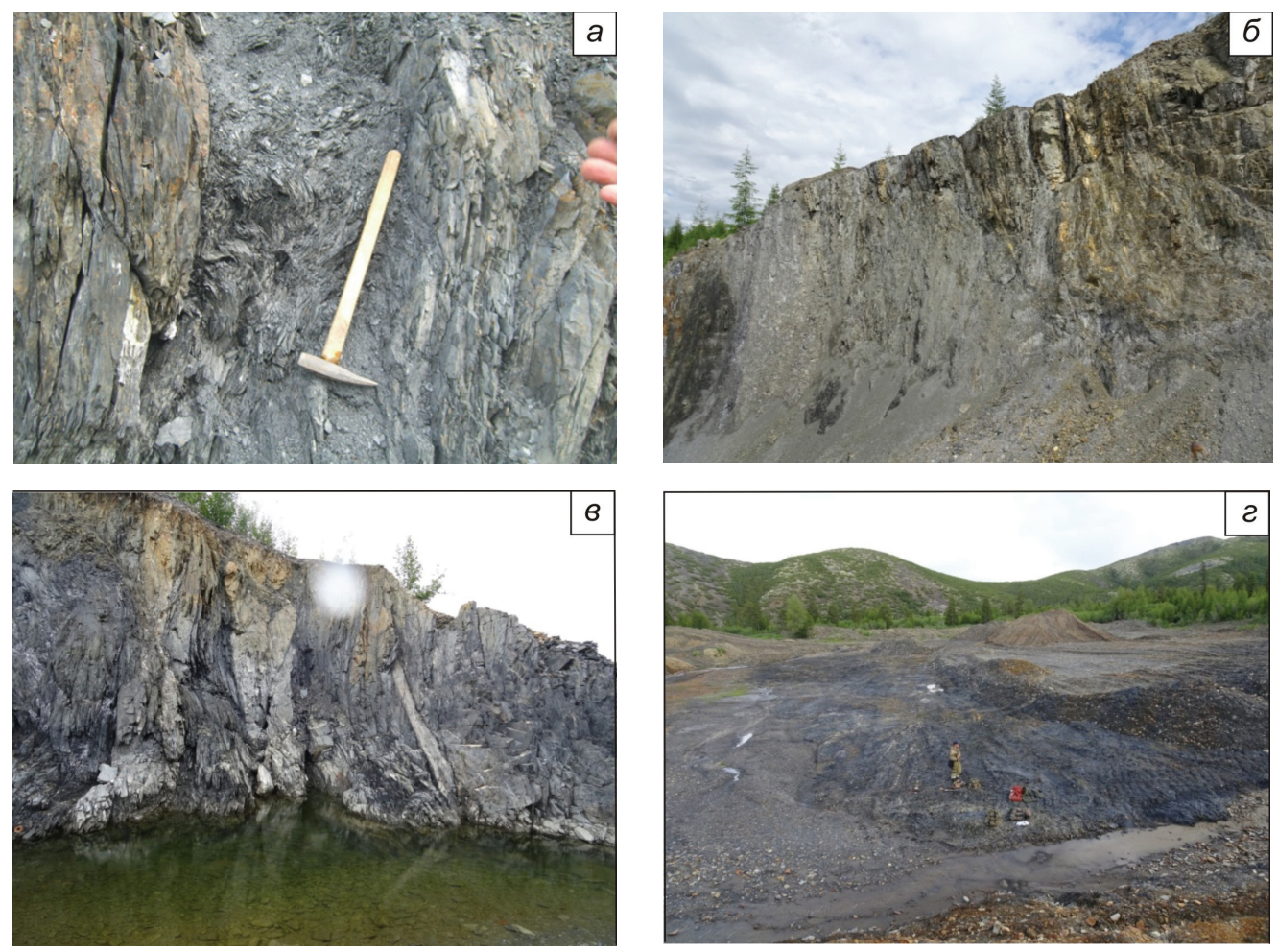

Puc. 2. Фрагменты зон изученных разломов: $a$ - Дебинского - руч. Спокойный; $\sigma$ - Чай-Юрьинского руч. Чай-Юрья, в, г - Оротукано-Среднеканского (в - бассейн руч. Приискатель, г - верховья р. Лев. Среднекан)

Fig. 2. Fragments of the studied fault zones: $a$ - Debin - Spokoyny Creek; $\sigma$ - Chay-Yurya - Chay-Yurya Creek, $b$, z-Orotukan-Srednekan ( 6 - Priiskatel' Creek basin, 2 - upper reaches of the Left Srednekan River) 
лена тектоническими швами мощностью первые метры, разделяющими блоки разно деформированных пород, вплоть до появления складок с вертикальным шарниром с размахом крыльев в первые метры. В бассейнах указанных ручьев отобраны пробы по профилям, пересекающим основные структуры. Сам разлом сопровождается зоной метаморфически преобразованных пород шириной 2.5-3 км прогрессивной (биотиткордиерит-ильменит) и регрессивной (фенгиткарбонаты-сульфиды) стадий метаморфизма с золотоносным пиритом (1.12 г/т по 14 пробам), образовавшимся на последней стадии (Бабкин и др., 2001).

Третьим объектом была зона Среднеканской ветви Оротукано-Среднеканского разлома (Среднеканский участок). Участок расположен в истоках Правого Среднекана, в пределах которого в плотиках реки и ее притоков была опробована зона разлома, состоящая из нескольких тектонических швов разной мощности и степени деформирования (см. рис. 2). Они представляют собой зоны брекчированных пород мощностью до 10 м, которую сопровождают лежачие и малоамплитудные опрокинутые складки, участки интенсивно будинированных пород, многочисленные жилы и прожилки кварца.

Во всех случаях вмещающими породами являются триас-юрские терригенные песчаносланцевые отложения (переслаивание тонкозернистых песчаников, алевролитов и аргиллитов) с преобладанием алевролитов и аргиллитов. Следует также отметить, что в зонах разломов постоянно устанавливается присутствие большого количества кварцевых жил и даек разного состава (долеритов, порфиритов, гранодиорит- и гранитпорфиров).

\section{ОБЩАЯ ХАРАКТЕРИСТИКА ЗОН РАССЕЯННОЙ СУЛЬФИДИЗАЦИИ И ТИПЫ ПИРИТА}

В терригенных толщах наиболее часто встречаются пирит и пирротин (Измайлов, 1976; Крутоус, 1991; и др.). В 1976 г. в обширном отчете, значение которого со временем не изменилось, М. Л. Гельман с соавторами подсчитали, что из 622 зон сульфидизации на всем СевероВостоке Азии их большая часть мезозойские $(85 \%)$ и в трети из них, помимо пирита и пирротина, отмечены галенит, арсенопирит, сфалерит, халькопирит и другие минералы (Бабкин и др., 2001). Параметры зон не всегда определены, но в тех случаях, когда они определены, ширина зон колеблется от первых метров до 56 км (обычно 0.1-2 км), а длина - от сотен метров

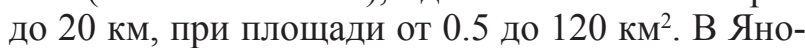
Колымском поясе выявлена 121 такая зона. Из них $60 \%$ - это пиритовые и пирит-пирротиновые зоны, 24\% - многосульфидные и остальные минералогически не исследованы.

По наблюдениям указанных исследователей и нашим данным, пирит в таких зонах встречается в виде метакристаллов кубической формы, размерами до 20-30 мм по ребру и в виде глобулярных лентовидных микрообособлений тонкозернистого строения. Общее количество его обычно $1-3 \%$, иногда достигает 30\%. Нередки конкреции размером от 1.5 до 25-70 см, обычно не более до 10-20 см в поперечнике. Следует отметить первичную природу глобулярного пирита и метагенетичный характер кристаллического пирита, что отчетливо наблюдается в конкрециях. Как правило, обогащенные пиритом участки тяготеют к границам слоев или к песчанистым прослоям среди глинистых сланцев.

В результате проведенных наблюдений в зонах рассматриваемых разломов, равно как и в разнотипно дислоцированной слоистой толще макроскопически выделено шесть типов пирита: (1) пылеватый, тонкий; (2) мелкокубический (0.5-5 мм); (3) крупнокубический (от 5 до 20 30 мм), (4) конкреционный, (5) прожилковый по все секущим трещинам и (6) жильный в кварце разнообразных жил, локализованных в 3онах разломов и среди осадков складчатой толщи. Отмеченные Л. И. Измайловым (1976) пентагондодекаэдрические формы нами не встречены, что совпадает с наблюдениями Л. В. Фирсова (1963). По форме локализации это обычно рассеянная вкрапленность, реже полосы (горизонты осадков), обогащенные вкрапленным пиритом, и совсем редко пиритовые прожилки и просечки мощностью в первые миллиметры и доли миллиметра (рис. 3). Отмечено, что крупнокубический пирит более характерен для внутренней зоны ореолов пиритизации, и он распределен неравномерно, а остальные морфологические типы - более равномерно. Пирит всех этих типов обычно тяготеет то к песчаникам, то к алевролитам, но иногда развивается и по всем литологическим разностям.

Микроскопические исследования (оптический микроскоп и электронный микроскоп с аналитическими приставками) показали, что, помимо пирита - главного рудного минерала, в изученных участках редко встречается пирротин и совсем редко - халькопирит, галенит, сфалерит и арсенопирит. Выявлены также в единичных случаях минералы никеля и кобальта, а также включения золота в пирите.

Пирит. Наблюдения под микроскопом показали, что пылеватый пирит нередко представлен выделениями фрамбоидального облика правильной сферической формы диаметром от 21 до 140 мкм. Фрамбоиды сложены индивидуальными равновеликими микрокристаллами пирита размером 2.5-3 мкм (рис. $4 a, \sigma)$, иногда с ми- 

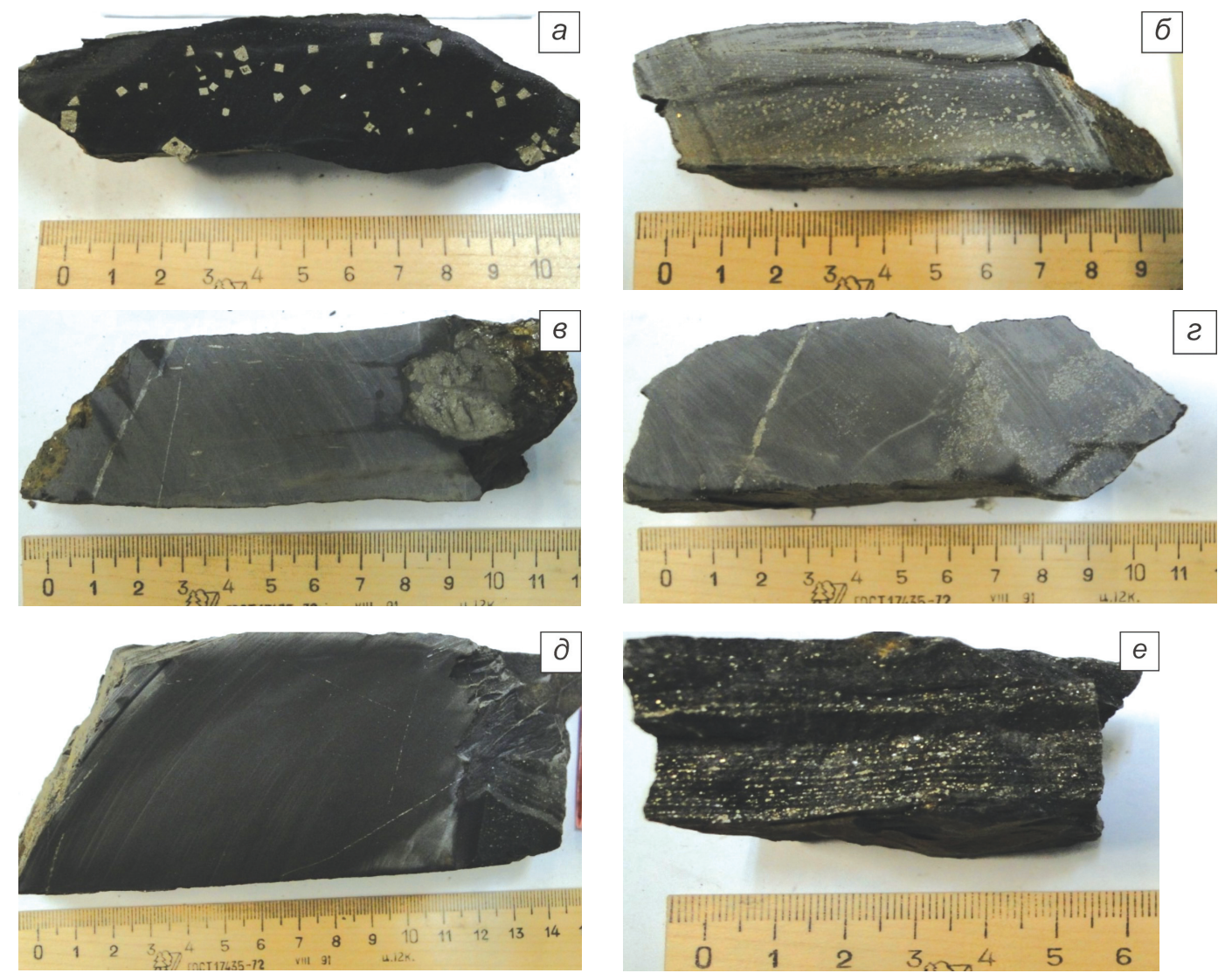

Рис. 3. Рассеянная вкрапленность крупнокубических кристаллов пирита в глинистом сланце (обр. 7-2018, участок «Спокойный») (a); алевролит с обильной вкрапленностью мелкокубического пирита (обр. 2120, участок «Озернинский») (б); конкреционный пирит и его мелкие тонкие линзочки в глинистом сланце (обр. 2025, участок «Спокойный») (в); алевролит с тонкими прожилками и «облачными» скоплениями мелкокубического пирита (обр. 2074, участок «Чай-Юрья») (2); алевролит с нитевидными прожилками пирита (обр. 2070, участок «Чай-Юрья») (d); послойная вкрапленность мелкокубического пирита (e) (обр. М-1056, участок «Озернинский»)

Fig. 3. Dispersed impregnation of large-cubic pyrite crystals in clay slate (Sample 7-2018, Spokoyny site) (a); aleurolite with massive impregnation of fine-cubic pyrite (Sample 2120, Ozyorninsky site) (б); concretional pyrite and its fine thin lenslets in clay slate (Sample 2025, Spokoyny site) (8); aleurolite with fine veinlets and "cloudy" concentrations of fine-cubic pyrite (Sample 2074, Chay-Yurya site) (2); aleurolite with threads of pyrite (Sample 2070, ChayYurya site) $(\partial)$; layer-by-layer impregnation of fine-cubic pyrite (e) (Sample M-1056, Ozyorninsky site)

кровключениями рутила. Такие формы присущи пириту первично осадочного происхождения (Berner, 1984; Астафьева и др., 2005; и др.). В составе фрамбоидального пирита зоны ЧайЮрьинского разлома отмечено присутствие мышьяка 0.6-0.8\% (руч. Чай-Юрья) или кобальта и никеля - 1.2-1.5 и 0.65-1.9\% соответственно (руч. Озерный) (табл. 1). Кроме того, нередко наблюдаются конкреции марказита размером от 30 до 130 мкм, имеющие удлиненную и изометричную форму и концентрическизональное строение, иногда развитие конкреции происходит по пирротину (рис. 4, в). В более крупных выделениях такой пирит (марказит?) образует конкреции изометричной, удлиненной, почковидной формы с массивным, зернистым, концентрически-зональным строением (рис. 4, 2). Для него примеси нехарактерны.

Большая же часть пирита представлена разнозернистыми кристаллическими скоплениями, об- разующими отдельные обособления в виде гнезд и линз. Как показано выше, мы подразделяем их в соответствии с морфологическими особенностями и размерами на мелкокубическую (МК) и крупнокубическую (КК) разновидности.

Мелкокубические кристаллы пирита размером от 0.1 до 5 мм широко распространены и представлены квадратными, прямоугольными и треугольными сечениями (см. рис. $4,2-3)$. Состав пирита на всех изученных участках близок к стехиометрическому. Но иногда в пирите зон Дебинского и Чай-Юрьинского разломов появляется примесь Co (2.06-6.30 мас.\%) или $\mathrm{Ni}$ (до 0.52 мас.\%) и $\mathrm{As}$ (от 0.38 до 1.16 мас.\%) (см. табл. 1).

Большая часть МК пирита представлена срастаниями зерен кубической формы (см. рис. 4, 2 ), нередко с включениями халькопирита, реже сфалерита (рис. 5).

Размер включений этих минералов достигает 15 мкм. 


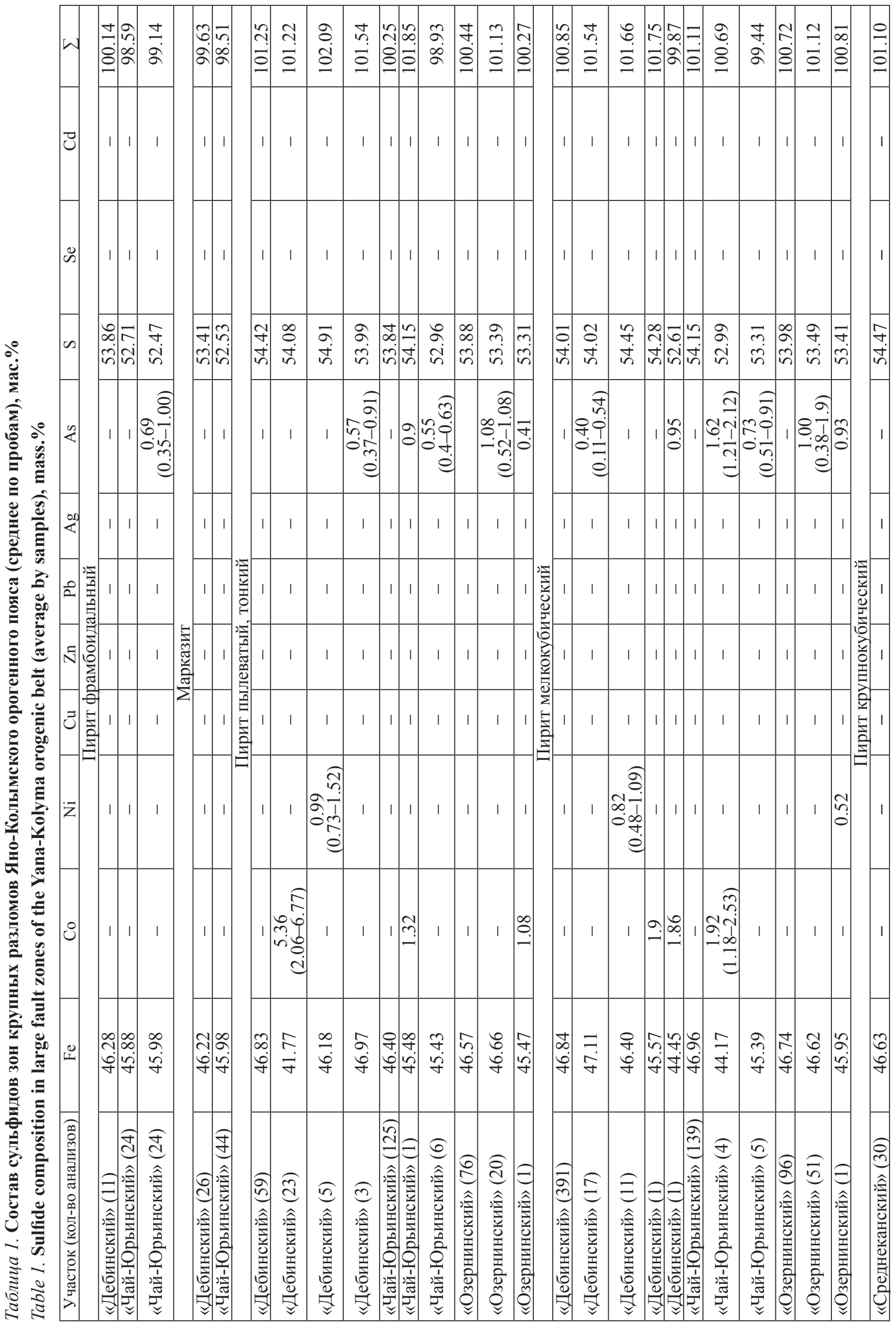




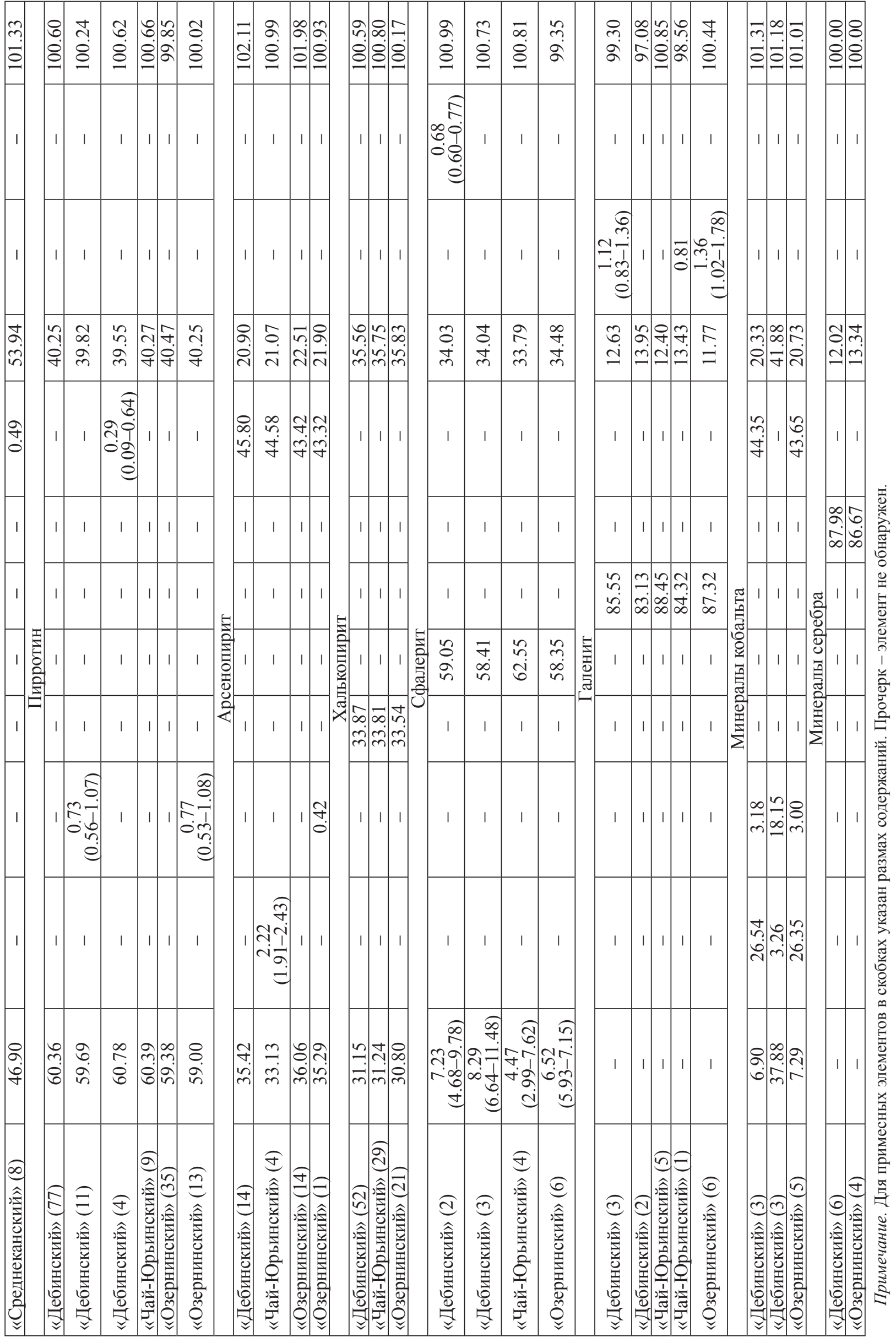




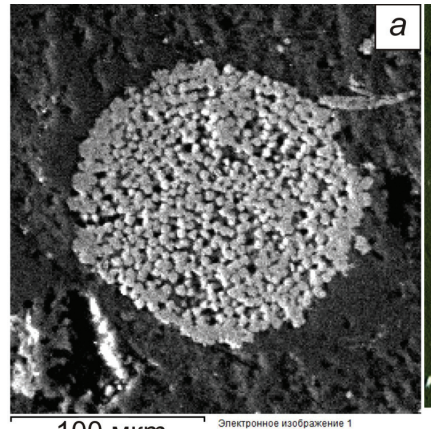

$100 \mathrm{Mkm}$

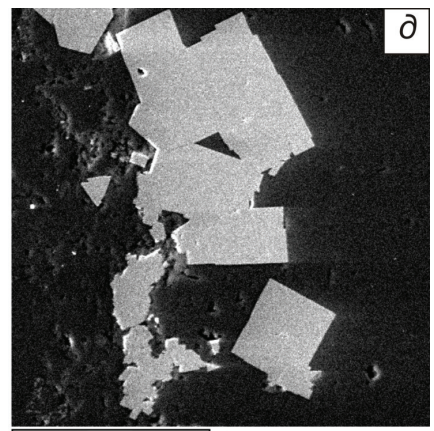

$100 \mathrm{mkm}$

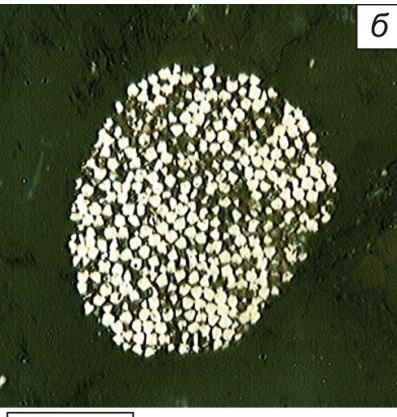

20 мкт

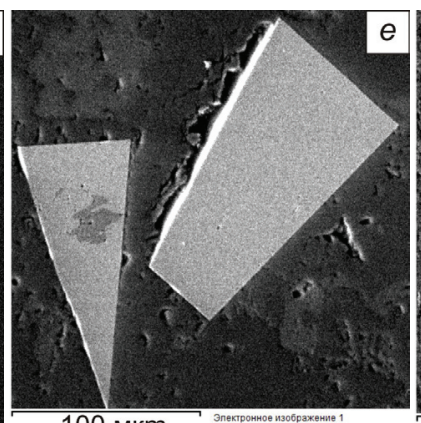

$100 \mathrm{Mkm}$

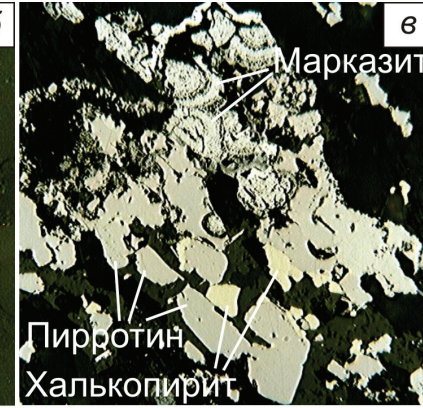

$100 \mathrm{mkm}$

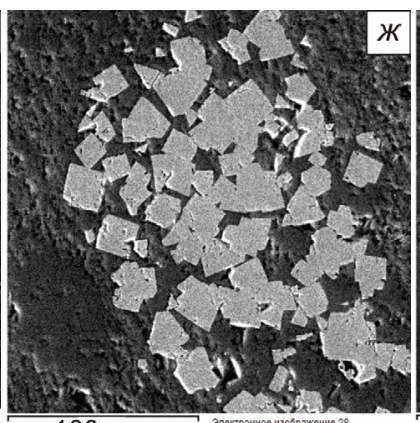

$100 \mathrm{Mkm}$

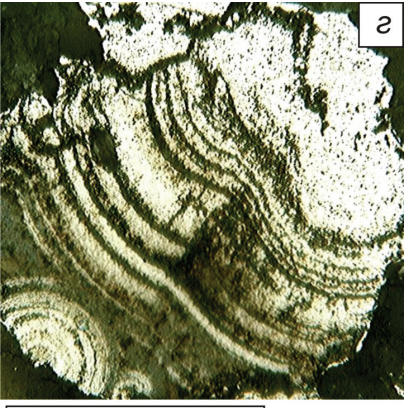

100 мкт

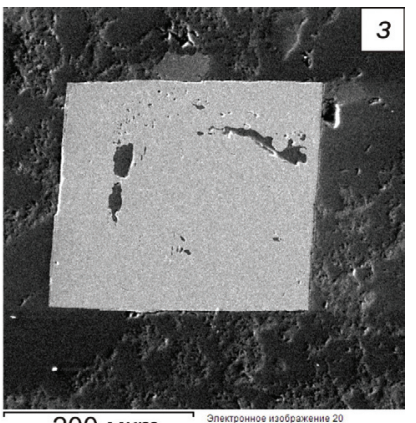

200 мкm

Puc. 4. Фрамбоидальный пирит в зоне Чай-Юрьинского разлома в алевролите (обр. 2053) (a) и в песчанике (обр. 1035/2) (б), р. Чай-Юрья; конкреции марказита удлиненной формы концентрически-зонального строения, развивающиеся по пирротину (обр. 2023) (в); изометричные конкреции пирита (марказита) в алевролите из отвала коренных пород, р. Чай-Юрья (обр. 2073) (2); идиоморфные кристаллы пирита обр. 1-2018, руч. Спокойный (д); обр. 2022, руч. Матросова (е); обр. 2062, р. Чай-Юрья (ж); обр. 2119, участок «Озернинский» (з)

Fig. 4. Framboidal pyrite in the zone of the Chay-Yurya fault, in aleurolite (Sample 2053) (a) and in sandstone (Sample 1035/2) (б), Chay-Yurya River; marcasite concretions, elongated in shape, concentrically zoned in structure, developing on pyrrhotine (Sample 2023) (B); isometric concretions of pyrite (marcasite) in aleurolite from bed-rock pile, Chay-Yurya River (Sample 2073) (2); idiomorphic crystals of pyrite, Sample 1-2018, Spokoyny Creek (d); Sample 2022, Matrosov Creek (e); Sample 2062, Chay-Yurya River (ж); Sample 2119, Ozyorninsky site (з)
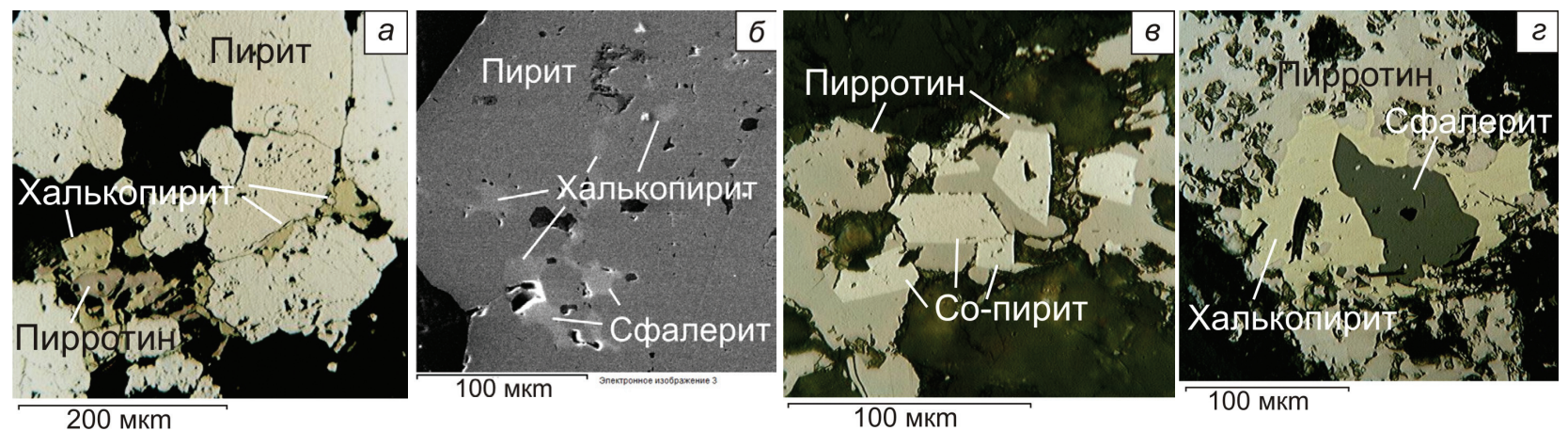

Рис. 5. Микровключения халькопирита в пирите (обр. 1-2018), руч. Спокойный) (a); микровключения халькопирита и сфалерита (обр. 1035/2), участок «Чай-Юрья» (б); Со-пирит в сростке с пирротином (обр. 1012/7, руч. Матросова, участок «Дебинский») (в); срастания пирротина с халькопиритом и сфалеритом (обр. 1051/1), руч. Озерный (2)

Fig. 5. Chalcopyrite microinclusions in pyrite (Sample 1-2018, Spokoyny Creek) (a); microinclusions of chalcopyrite and sphalerite (Sample 1035/2), Chay-Yurya site (б); Co-pyrite intergrown with pyrrhotine (Sample 1012/7, Matrosov Creek, Debin site) (8); pyrrhotine intergrowths with chalcopyrite and sphalerite (Sample 1051/1), Ozyorny Creek (2)

КК пирит иногда образует кубические кристаллы до 3 см по ребру. Он проявлен в зонах всех изученных разломов, но наиболее крупный обнаружен в зоне Среднеканского разлома, где он сформировался в виде «рубашки» кристал- лов на округло-овальных будинах филлитизированных алевролитов. В составе его оптически и электронно-оптически однородного кристалла отмечаются участки кристаллов, обогащенные мышьяком (до $0.65 \%$ ), незакономерно чередую- 
щиеся с участками со стехиометрическим беспримесным составом (рис. 6). Пирит ассоциирует с серицитом и карбонатом (см. рис. 6).

Пирротин представлен как мелкими самостоятельными зернами размером от 5-10 мкм, так и более крупными агрегатными срастаниями размером до 150 мкм (рис. 7). Иногда в пирротине содержится примесь $\mathrm{Ni}$ до $1 \%$ (см. табл. 1). По нашим наблюдениям, он не так широко распространен, как было показано Л. И. Измайловым (1976).

Наблюдаются также сростки пирротина с Coпиритом, халькопиритом и сфалеритом (см. рис. 5). Халькопирит отличается стехиометричным беспримесным составом. А вот сфалерит по составу разделяется на две разновидности: высокожелезистую (10-15\% Fe с единичным присутствием кадмия - $0.6 \%)$ в зоне Дебинского разлома и менее железистую (3-7\% Fe) в зоне ЧайЮрьинского разлома (см. табл. 1).

Арсенопирит встречается довольно редко и представлен как мелкими включениями в пирите размером до 20 мкм, так и самостоятельными кристаллами размером до 120 мкм (рис. 8). На данной стадии изученности он отмечен в зонах Дебинского и Чай-Юрьинского разломов. Для арсенопирита зоны Чай-Юрьинского разлома характерно присутствие примеси $\mathrm{Ni}$ (до 0.42 мас.\%) или Со (до 2.38 мас.\%) (см. табл. 1).
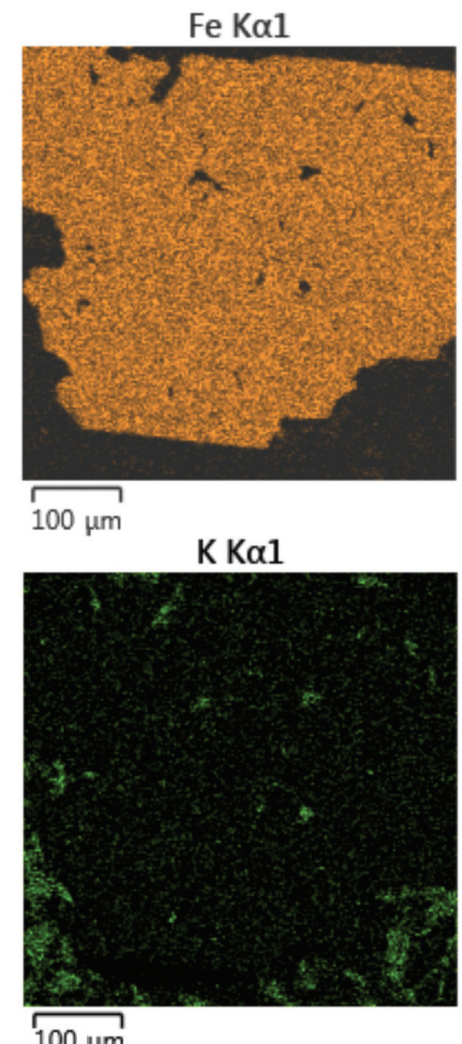

$\overparen{100 \mu \mathrm{m}}$

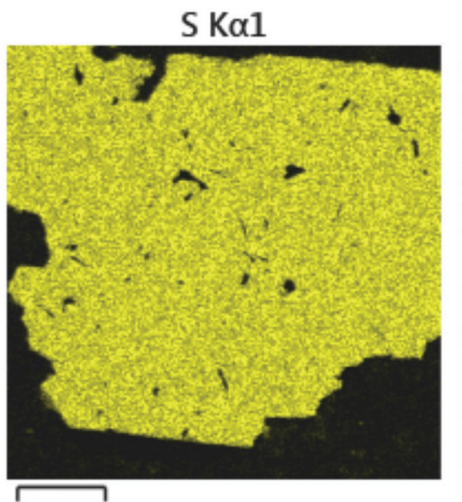

$100 \mu \mathrm{m}$

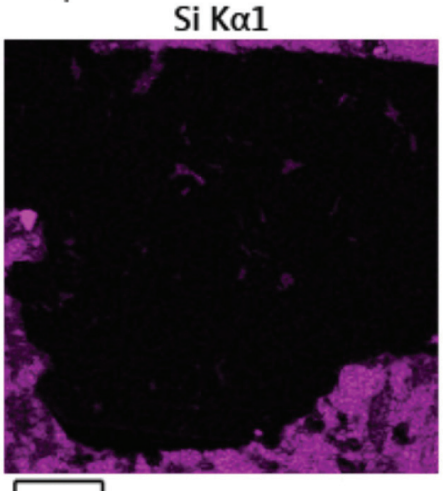

$\overparen{100 \mu \mathrm{m}}$

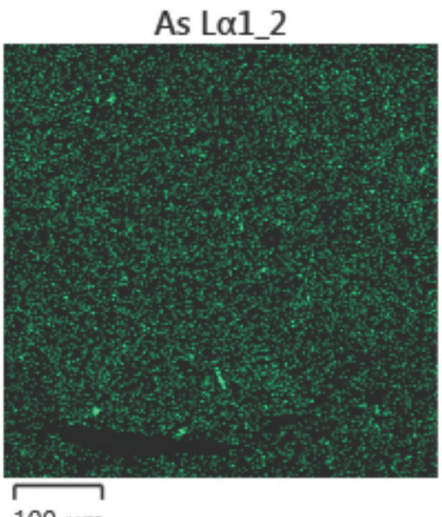

$100 \mu \mathrm{m}$

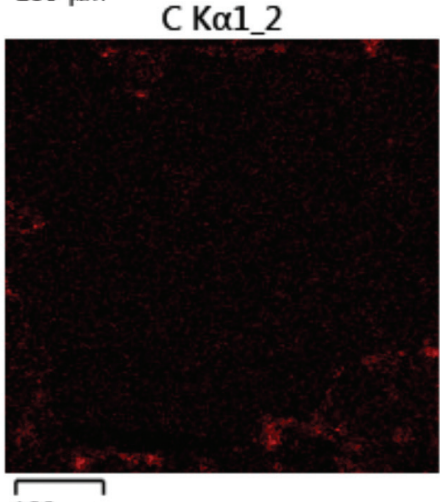

$100 \mu \mathrm{m}$

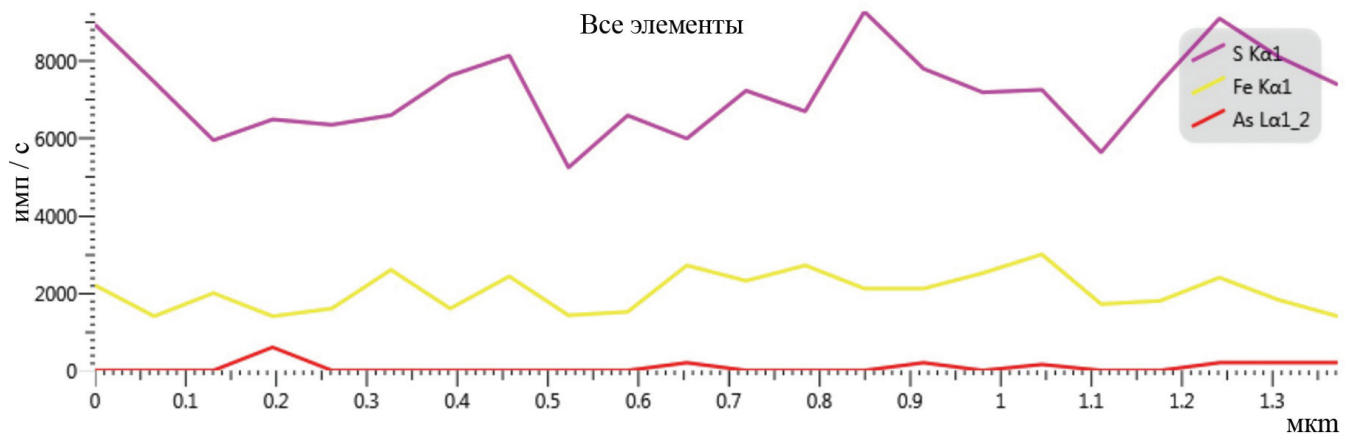

Рис. 6. Распределение элементов в пирите и окружающем его пространстве, обр. 160, участок «Среднеканский». Внизу деталь профиля с высоким разрешением, показывающая неоднородное распределение мышьяка в пирите

Fig. 6. Distribution of elements in pyrite and in the space around it, Sample 160, Srednekan site. Bottom: profile detail with high resolution, showing uneven distribution of arsenic in pyrite 


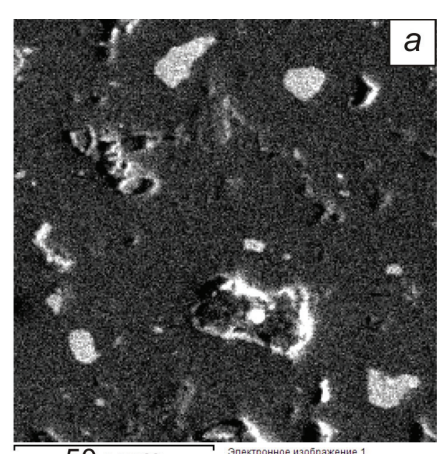

50 мкm

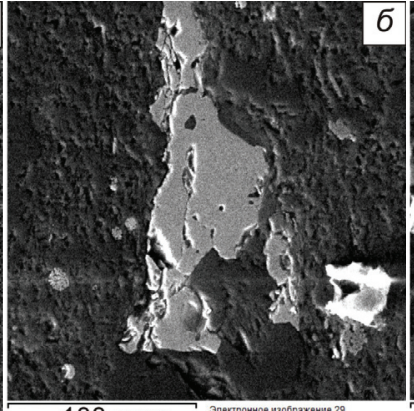

$100 \mathrm{mkm}$

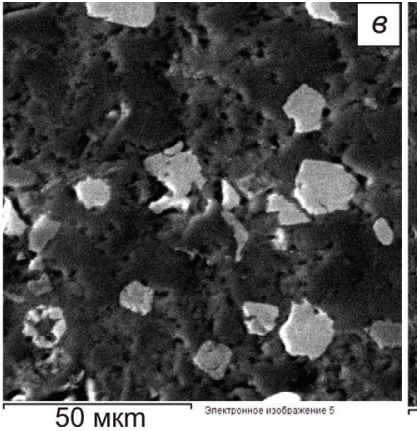

$50 \mathrm{MKm}$

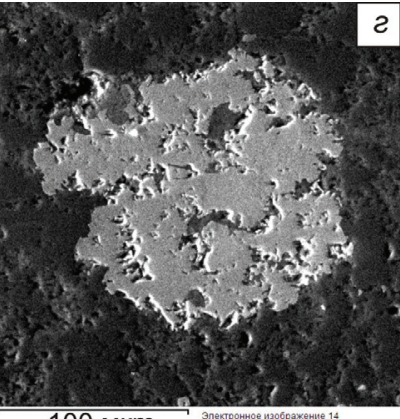

$100 \mathrm{MKm}$

Рис. 7. Зерна пирротина (обр. 2008) (a); пирротин в альбите (обр. 2062), руч. Фролыч, участок «Чай-Юрья» (б); мелкие зерна (в) и агрегатные срастания (2) пирротина (обр. 2117), руч. Озерный

Fig. 7. Pyrrhotine grains (Sample 2008) (a); pyrrhotine in albite (Sample 2062), Frolych Creek, Chay-Yurya site (б); fine grains (b) and aggregate intergrowths (2) of pyrrhotine (Sample 2117), Ozyorny Creek

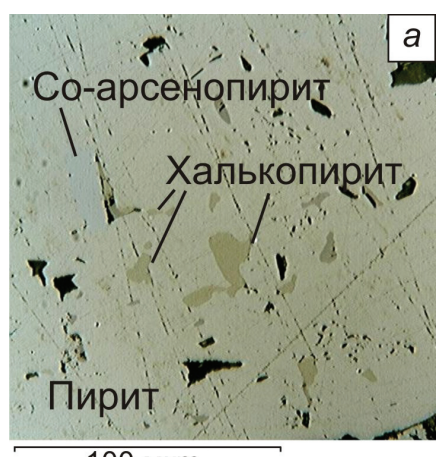

$100 \mathrm{MKm}$

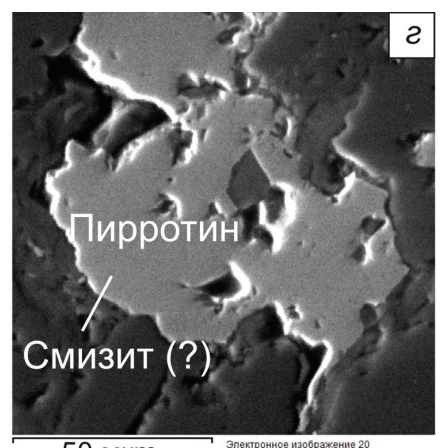

50 мкm

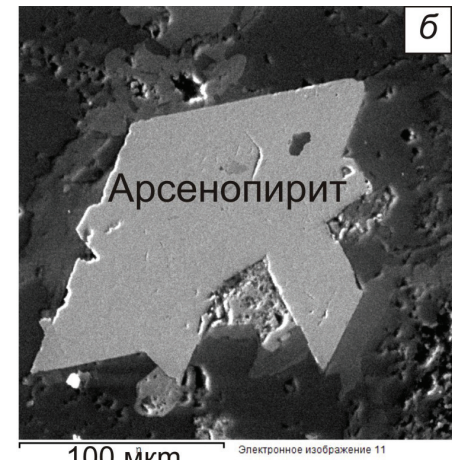

100 мкm

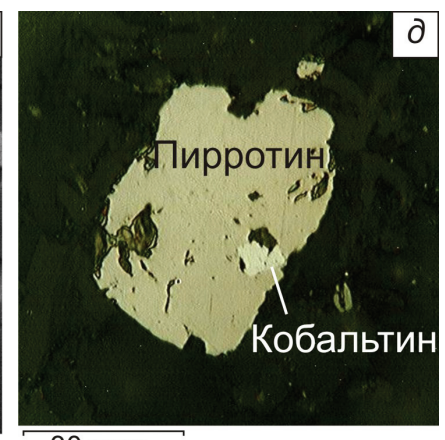

30 мкm
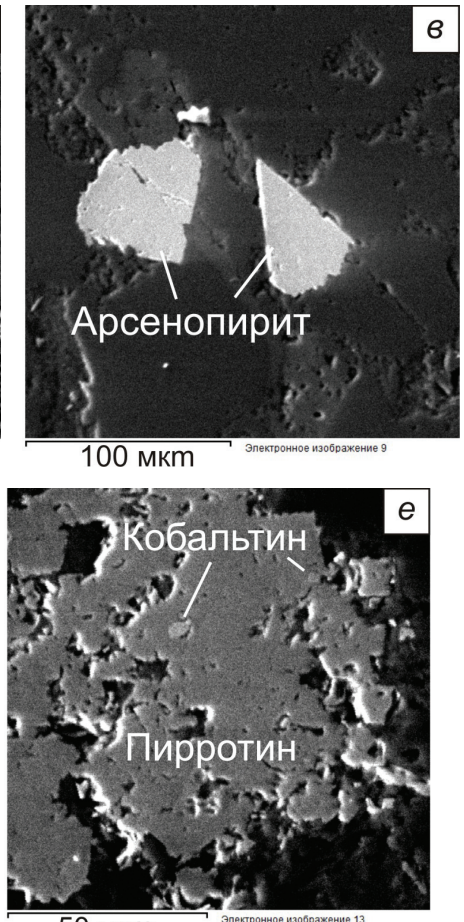

50 мкm

Рис. 8. Включения Со-арсенопирита и халькопирита в пирите и алевролите из отвала коренных пород, p. Чай-Юрья (обр. 2073) (a); арсенопирит в карбонатизированном песчанике, руч. Матросова (обр. 2019), участок «Дебинский» (б); арсенопирит в песчанике (обр. 1057/2), руч. Озерный (в); микровключения смизита (?) (2) и кобальтина (d), руч. Матросова (обр. 1012/7), участок «Дебинский»; кобальтин в пирротине (обр. 2117, полотно полигона), участок «Озернинский» $(e)$

Fig. 8. Co-arsenopyrite and chalcopyrite inclusions in pyrite and aleurolite from the bed-rock pile, Chay-Yurya River (Sample 2073) (a); arsenopyrite in carbonatized sandstone, Matrosov Creek (Sample 2019), Debin site (б); arsenopyrite in sandstone (Sample 1057/2), Ozyorny Creek (b); microinclusiong of smithite (?) (2) and cobaltine ( $\partial$ ), Matrosov Creek (Sample 1012/7), Debin site; cobaltine in pyrrotine (Sample 2117, site surface), Ozyorninsky site (e)

Минералы никеля и кобальта представлены единичными находками в виде мелких микровключений (около 5 мкм) в пирротине в зонах Чай-Юрьинского и Дебинского разломов. Так, в зоне Дебинского разлома, в алевролите с тонкими прослоями сульфидов и мелкими кварцевыми прожилками присутствует мелкое микровключение железо-никелевого сульфида - предположительно смизит - в зерне пирротина (руч. Матросова) (рис. 8; см. табл. 1). А в алевролите с вкрапленностью и прожилками сульфидов в зоне Чай-Юрьинского и Дебинского разломов в агрегате пирротина найдены микровключения кобальтина (полотно полигона, участок «Озернинский» и участок «Дебинский», руч. Матросова (см. рис. 8; см. табл. 1). 
В зоне Дебинского разлома в одном зерне пирита (обр. 2023, левый борт руч. Матросова) отмечены микровключения (около 1-2 мкм) самородного золота пробностью 786-821\%о и селенсодержащего (0.83 до 1.36 мас.\%) галенита (12 мкм) (рис. 9) (см. табл. 1). Галенит также обнаружен в виде мельчайших вкрапленников в краевых частях кристаллов КК пирита в зоне Оротукано-Среднеканского разлома.

\section{ИЗОТОПНО-ГЕОХИМИЧЕСКАЯ ХАРАКТЕРИСТИКА}

Данные эмиссионного количественного спектрального анализа опробования по профилям вкрест разломов на обсуждаемых участках и опробования самих зон в плотиках россыпей показали, что, несмотря на низкую чувствительность анализа, в их пределах появляются повышенные содержания $\mathrm{As}, \mathrm{Ag}, \mathrm{Sb}, \mathrm{Ni}, \mathrm{Co}, \mathrm{Pb}, \mathrm{Cu}, \mathrm{Zn}$ и даже $\mathrm{Au}$,
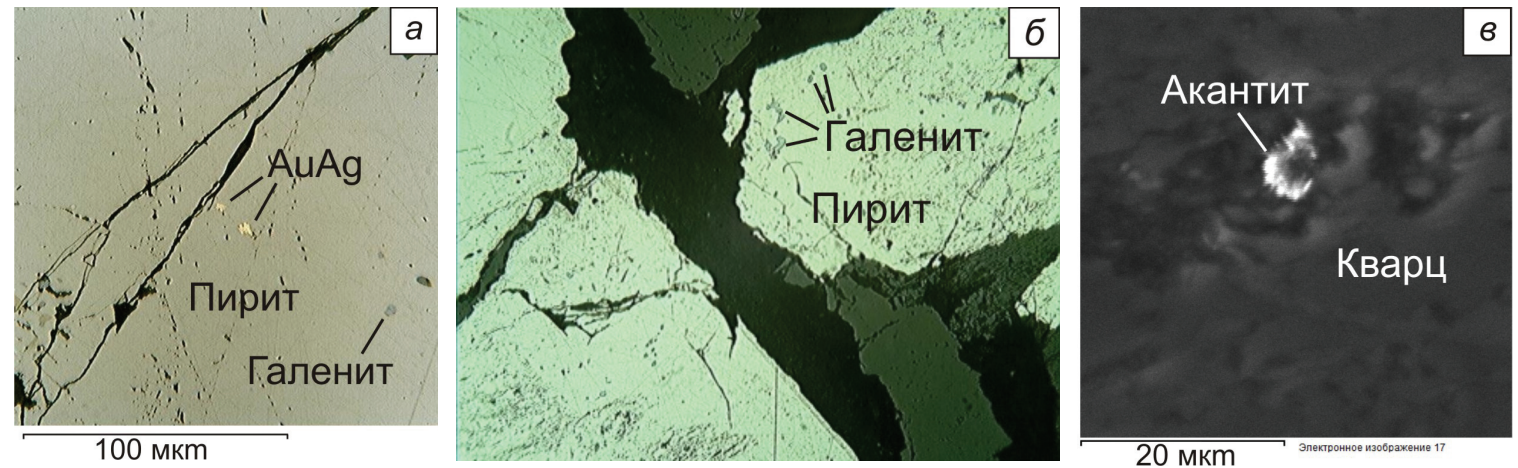

Рис. 9. Микровключения самородного золота и галенита (a) в пирите (обр. 2023), руч. Матросова, участок «Дебинский», галенита в обр. 160-гр-19 (б) и акантита, р. Бахапча (обр. 1067/1), участок «Дебинский» (в)

Fig. 9. Microinclusions of native gold and galena (a) in pyrite (Sample 2023), Matrosov Creek, Debin site, galena in Sample 160-гр-19 (б), and acanthite, Bakhapcha River (Sample 1067/1), Debin site (в)

В одной из проб на левом берегу р. Бахапча в аргиллите без видимой минерализации, помимо пирита, установлены микровключения акантита размером до 5 мкм.

Акантит образует как единичные мелкие включения (1-2 мкм), так и более крупные агрегаты (5 мкм), состоящие из сросшихся копьевидных и шестоватых кристаллов в интерстициях сростков глинистых минералов, кварца и хлорита (см. рис. 9,8; табл. 1). Также включение акантита обнаружено в кристалле пирита, участок «Озернинский».

Таким образом, проведенное изучение показывает присутствие в зонах сульфидизации, приуроченных к зонам крупных разломов, достаточно широкого спектра сульфидных и других минералов, характерных для золоторудных объектов, при существенном преобладании пирита разных морфологических типов и пирротина.

Обращают на себя внимание редкие находки галенита, акантита и минералов кобальта и никеля, а также периодическое присутствие мышьяка в пирите, а кобальта и никеля в пирите, пирротине и арсенопирите. Следует отметить, что на данной стадии изученности все находки такого разнообразия сульфидных минералов характерны только для зон сульфидизации в непосредственной близости от тектонических швов. практически отсутствующие в сульфидных ореолах за пределами зон разломов. При этом «фонят» не только кварцевые жилы с сульфидами и дайки, но и участки (не все) со вкрапленностью пирита разной морфологии. Это фиксируется в отдельных «выплесках» содержаний в единичных пробах из зон сульфидизации изученных разломов по данным количественного эмиссионного спектрального анализа, г/т: As (до 3600), Co (до 227), $\mathrm{Ni}$ (до 126), Сu (до 117), $\mathrm{Pb}$ (до 100) и $\mathrm{Zn}$ (до 500), совпадающим с данными атомно-абсорбционного анализа (табл. 2). Приведенные выше материалы по особенностям химического состава пирита и по его минералам-спутникам предполагают их ответственность за такие «выплески».

Нами были получены первые результаты по микроэлементному составу КК пирита (ICPMS анализ) из зоны Среднеканского разлома (табл. 3), которые показали неоднородное распределение As от 143-220 г/т в его кристаллах, где по данным микрорентеноспектрального анализа было отмечено блоковое обогащение As, до 22-34 г/т в других кристаллах меньшего размера. Характерны также постоянное присутствие во всех изученных кристаллах Со (77-148 г/т), $\mathrm{Au}(0.171-0.714$ г/т), Ag (0.2-0.3 г/T), Bi (2.34.3 г/т) и низкие содержания $\mathrm{Pd}(3.4-12.7 \mathrm{мг} / \mathrm{T})$ и $\mathrm{Pt}(2.0-8.3 \mathrm{мг} / \mathrm{T})$, неравномерные $\mathrm{Ni}-$ от $64-65$ г/т в мышьяковистом пирите до 14.8-37.7 г/т в чистом пирите. 
Таблица 2. Рудогенные элементы-примеси в сульфидизированных образованиях зон разломов Table 2. Ore-caused admixture elements in sulfidized formations of fault zones

\begin{tabular}{|c|c|c|c|c|c|c|c|c|c|}
\hline \multirow{2}{*}{ Характеристика объекта } & \multirow{2}{*}{$\begin{array}{l}\text { Кол-во } \\
\text { проб }\end{array}$} & \multicolumn{8}{|c|}{ Элемент, г/т } \\
\hline & & As & $\mathrm{Au}$ & $\mathrm{Ag}$ & $\mathrm{Cu}$ & $\mathrm{Zn}$ & $\mathrm{Pb}$ & $\mathrm{Ni}$ & Co \\
\hline \multicolumn{10}{|c|}{ Зона Дебинского разлома, участок «Дебинский» } \\
\hline Рудные прожилки в дайках & 5 & 276 & 2.91 & 0.24 & 61.8 & 118.5 & 38.9 & 42.2 & 18.9 \\
\hline $\begin{array}{l}\text { Сульфиды в зонах милонитов и дроб- } \\
\text { ления тектонических швов }\end{array}$ & 10 & 660 & 0.19 & 1.41 & 117.9 & 110.9 & 84.2 & 122.5 & 74.2 \\
\hline $\begin{array}{l}\text { Сульфиды в осадках в зонах влияния } \\
\text { тектонических швов, но на удалении } \\
\text { от них }\end{array}$ & 10 & $\leq 5.35$ & 0.05 & 0.21 & 59.7 & 125.4 & 30.2 & 65.3 & 21.3 \\
\hline Метаморфогенный кварц с пиритом & 7 & $\leq 5.35$ & 0.04 & 0.31 & 35.5 & 91.7 & 11.2 & 17.2 & 6.5 \\
\hline \multicolumn{10}{|c|}{ Зона Среднеканского разлома, участок «Среднеканский» } \\
\hline $\begin{array}{l}\text { Сульфиды в зонах милонитов и дроб- } \\
\text { ления }\end{array}$ & 3 & Не опр. & 0.03 & 2.48 & \multicolumn{5}{|c|}{ Не определялось } \\
\hline $\begin{array}{l}\text { Сульфиды в зонах влияния тектони- } \\
\text { ческих швов }\end{array}$ & 4 & Не опр. & 0.03 & 0.36 & \multicolumn{5}{|c|}{ Не определялось } \\
\hline
\end{tabular}

Примечание. As - эмиссионный количественный спектральный анализ (СВКНИИ ДВО РАН, аналитик Т. П. Козырева), остальные элементы - атомно-абсорбционный анализ (СВКНИИ ДВО РАН, аналитик В. П. Колесова).

Таблица 3. Благородные и рудные элементы (г/т) в кристаллах гидротермально-метаморфогенного пирита зоны Среднеканского разлома (данные ICP-MS анализа)

Table 3. Precious and ore elements grade (g/t) in hydrothermsl-metamorphogenic pyrite of the Srednekan fault zone (ICP-MS analysis data)

\begin{tabular}{|l|c|c|c|c|c|c|c|c|c|c|c|c|c|c|c|}
\hline \multicolumn{1}{|c}{ № пробы } & $\mathrm{Ru}$ & $\mathrm{Rh}$ & $\mathrm{Pd}$ & $\mathrm{Ir}$ & $\mathrm{Pt}$ & $\mathrm{Au}$ & $\mathrm{Cr}$ & $\mathrm{Co}$ & $\mathrm{Ni}$ & $\mathrm{As}$ & $\mathrm{Pb}$ & $\mathrm{Bi}$ & $\mathrm{Ag}$ & $\mathrm{Sb}$ & $\mathrm{W}$ \\
\hline 160 Б-Гр-19-1 & 0.02 & 0.09 & 3.36 & 0.74 & 8.28 & 171 & 7.7 & 100 & 64.3 & 143.5 & 31.8 & 2.44 & 0.27 & - & - \\
\hline 160 Б-Гр-19-2 & 0.10 & 0.06 & 4.32 & 0.55 & 2.07 & 714 & 15.5 & 148 & 64.7 & 220.5 & 21.6 & 2.28 & 0.19 & - & - \\
\hline 160 Б1-Гр-19-11 & 0.11 & 0.12 & 3.66 & 0.45 & 4.76 & 123.8 & 5.4 & 76.8 & 14.8 & 22.2 & 45.0 & 3.62 & 0.24 & - & 1.43 \\
\hline 160 Б1-Гр-19-12 & 0.02 & 0.16 & 12.66 & 0,49 & 3.97 & 205.1 & 7.1 & 105 & 37.7 & 34.5 & 70.2 & 4.26 & 0.34 & 6.11 & 0.22 \\
\hline 160 Б1-Гр-19-13 & 0.07 & 0.08 & 10.87 & 0.57 & 1.96 & 189.2 & 6.9 & 109 & 32.1 & 26.5 & 149 & 2.99 & 0.32 & 7.88 & 0.02 \\
\hline
\end{tabular}

Примечание. Прочерк - менее 0.001 г/т.

Кроме того отмечено присутствие сурьмы в маломышьяковистом пирите и ее отсутствие в мышьяковистом.

Помимо изучения микроэлементного состава было проведено исследование изотопного соста- ва серы пирита трех разновидностей: конкреционного, МК и КК пирита (табл. 4).

В результате выявлены широкие вариации изотопного состава пирита зон сульфидизации в разломах и в окружающем их пространстве.

Таблица 4. Изотопный состав серы сульфидов зон разломов Яно-Колымского пояса

Table 4. Isotopic composition of sulfide sulfur from fault zones of the Yana-Kolyma belt

\begin{tabular}{|c|c|c|c|c|}
\hline Разлом (объект) & № пробы & Минерал & Тип пирита & $\Delta^{34} \mathrm{~S}, \%$ \\
\hline \multirow{9}{*}{ Дебинский (ДБ) } & 5-1-гр-17 & Пирит & Рудный & -10.3 \\
\hline & 10A-гр-17 & То же & Рудный дайковый & -9.0 \\
\hline & $17-г p-17$ & Арсенопирит & Рудный & -11.2 \\
\hline & 91-гр-17 & Галенит & То же & -9.5 \\
\hline & $37-г р-17$ & Марказит & Конкреционный (юра) & +5.6 \\
\hline & $37-г p-17$ & Пирит & То же & +5.3 \\
\hline & 56-гр-17 & Сфалерит & В кварцевой жиле & -16.3 \\
\hline & 57-гр-17 & Пирит & КК (триас) & -35.6 \\
\hline & 162-гр-18 & То же & MK & -4.8 \\
\hline \multirow{4}{*}{ Чай-Юрьинский (ЧЮ) } & $110-г р-18$ & Пирит & Просечки МК & -4.4 \\
\hline & 110A-гр-18 & То же & MK & -10.7 \\
\hline & $113-г p-18$ & $-\rangle\rangle-$ & MK & -3.7 \\
\hline & $115-г p-18$ & $-\gg-$ & MK & -9.9 \\
\hline
\end{tabular}


Окончание табл. 2

\begin{tabular}{|c|c|c|c|c|}
\hline Объект & № пробы & Минерал & Тип пирита & $\Delta^{34} \mathrm{~S}, \%$ \\
\hline \multirow{4}{*}{ Чай-Юрьинский (ОЗ) } & $135-г p-18$ & Пирит & МК + конкр. (юра) & +11.7 \\
\hline & $136-г р-18$ & То же & MK & -2.0 \\
\hline & 138-гр-18 & $-\gg-$ & КК (юра?) & +11.6 \\
\hline & 142-гр-18 & $-\gg-$ & МК (триас?) & -20.3 \\
\hline \multirow{5}{*}{ Чай-Юрьинский (ХУ) } & ХУ-АП & Пирит & Конкреционный (триас) & -22.7 \\
\hline & 113-гр-19 & То же & КК & -17.6 \\
\hline & 134Б-гр-19 & $-\gg-$ & MK & -5.1 \\
\hline & 135В1-гр-19 & $-\rangle-$ & MK & -8.0 \\
\hline & 135B2-гр-19 & $-\rangle\rangle-$ & КК & -8.9 \\
\hline \multirow{9}{*}{ Среднеканский (СК) } & 148А-гр-19 & Пирит & МК (юра) & +1.8 \\
\hline & 160Ж-гр-19 & То же & КK & -14.8 \\
\hline & 160-гр-19 & $->\rangle-$ & Кристалл (центр) & -14.2 \\
\hline & 160-гр-19 & $-\gg-$ & Кристалл (край) & -14.6 \\
\hline & 160-гр-19 & $-\gg\rangle-$ & То же & -14.6 \\
\hline & $160-г р-19$ & $-\gg-$ & $-\gg-$ & -14.7 \\
\hline & 160-гр-19 & $-\gg-$ & Кристалл (промежуток) & -14.4 \\
\hline & 160-гр-19 & $-\gg-$ & То же & -14.4 \\
\hline & 160-гр-19 & $-\gg-$ & $-\gg-$ & -14.7 \\
\hline
\end{tabular}

При этом выяснилось, что МК пирит зоны Чай-Юрьинского разлома оказался с промежуточными значениями изотопного состава серы (-2 ...-8\%o). А специальные исследования зональности КК пирита из зоны Среднеканского разлома показали его однородность по изотопному составу серы с тенденцией к некоторому облегчению в краевых зонах (см. табл. 4), несмотря на неоднородное распределение мышьяка (см. рис. 6).

\section{ОБСУЖДЕНИЕ}

На рассматриваемых участках отчетливо выделяются две главные генетические группы пиритов: первичного осадочнодиагнетического фрамбоидального и конкреционного, который проявлен во всех изученных участках, и постдиагенетического МК и КК пирита, природа которого различна (Фирсов, 1963; Измайлов, 1976; Бабкин и др., 2001; Фридовский и др., 2018). Об этом свидетельствуют и наши данные по изотопному составу серы пирита, показавшие существенный разброс изотопных отношений в них - от +11.6 до $-35.6 \%$ (см. табл. 4 ) (рис. 10), а также материалы других исследователей (Гамянин и др., 2003).

С одной стороны, осадочно-диагенетический пирит отложений юры характеризуется преобладанием тяжелого изотопа серы, а аналогичный пирит из триасовых пород обладает аномально легкой серой (-10..-22.7\%), что соответствует в грубом приближении кривой изотопной эволюции серы морских вод
(Фор, 1989). При этом легкий по сере пирит обычен для терригенных осадков, а тяжелый больше отвечает пиритам, возникшим в присутствии значительных количеств органического углерода (Фор, 1989), что в общем соответствует условиям существования осадочных бассейнов в триасе и юре в нашем районе.

С другой стороны, значительная часть кристаллического пирита имеет изотопный состав серы, близкий или подобный таковому рудных образований Яно-Колымского пояса (-3.7...-10\%) (Гамянин, Горячев, 2000; Гамянин и др., 2003), что позволяет предполагать его гидротермальную

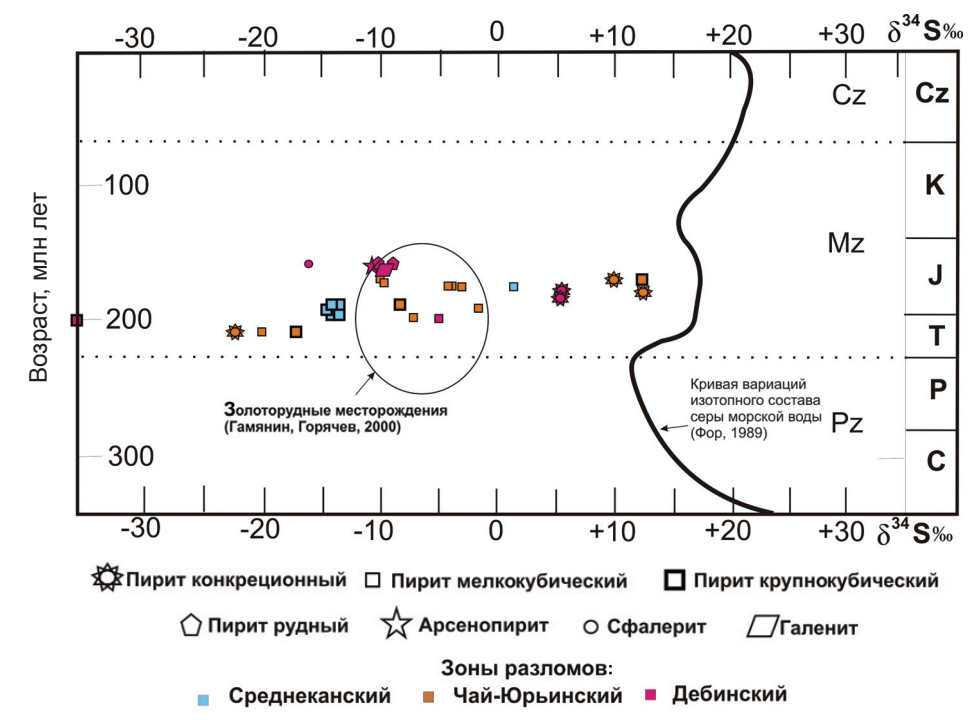

Puc. 10. Изотопный состав серы сульфидов зон разломов и прилегающих к ним сульфидных ареалов

Fig. 10. Isotopic composition of sulfide sulfur from fault zones and adjacent sulfide areas 
рудную природу. Кроме того, есть третья группа с изотопным составом, близким либо к тяжелым $(+1.8 \ldots 11.6 \%)$, либо к ультралегким $(-10 \ldots$ $-20 \%$ ) по сере первичным пиритам. Вероятно, в этой группе обособились метаморфогенные пириты, сохранившие изотопные связи с первичноосадочными разностями. И, наконец, особняком стоят ультралегкие по сере пирит и сфалерит из метаморфогенных кварцевых жил (-16..-35\%о). В данном случае скорее всего важнейшую роль сыграл кинетический фактор (Хефс, 1983).

Выявленное изотопное разнообразие пиритов и такие закономерности, а также характер распределения пирита в породах и его морфологические особенности предполагают вероятность разделения постдиагенетических пиритов на гидротермально-метаморфогенную и рудногидротермальную группы. Причем последней свойственны промежуточные изотопные отношения серы, обусловленные, по-видимому, смешанным источником серы как из осадочных пород юры и триаса, так и возможного эндогенного источника.

Состав основной массы пирита всех изученных участков близок к стехиометрическому, но иногда в нем отмечаются примеси $\mathrm{Co}, \mathrm{Ni}$ и $\mathrm{As}$ (см. табл. 1). Кроме того, нами выявлены в ассоциации с пиритом и редкие собственные минералы As, Co и Ni. На присутствие в единичных анализах этих элементов и $\mathrm{Sb}$ в пиритах зоны ЧайЮрьинского разлома ранее было указано В. Ю. Фридовским с соавторами (2018). Наши данные существенно расширяют количество находок такого пирита (см. табл. 1). Наличие во фрамбоидальном пирите примесей $\mathrm{As}, \mathrm{Ni}$ и $\mathrm{Zn}$ свидетельствует о том, что эти элементы в нем изначально связаны с процессами осадконакопления и диагенеза. Более поздние пириты могли унаследовать состав диагенетического пирита, определяя отдельные «выплески» на фоне отсутствия повышенных концентраций этих элементов в сульфидизированных толщах. Кстати, присутствие указанных элементов в осадочном пирите первым отметил Л. В. Фирсов (1963), показавший унаследованность его состава составом гидротермального пирита, названного им околожильным. Но присутствие минералов $\mathrm{Ni}$ и Co, наряду с повышенной кобальто- и никеленосностью пирротина и кристаллического пирита, указывает также и на активность данных элементов в метагенном минералообразующем флюиде и возможный их привнос этими флюидами. Важной особенностью позднего крупнокубического и реже мелкокубического гидротермального пирита является присутствие в них включений пирротина, галенита, сфалерита, халькопирита и золота, показанное нами и отмеченное ранее Л. И. Измайловым (1976) и В. Ю. Фридовским с соавторами
(2018). Наряду с геохимическими особенностями пирита, это позволяет предполагать генетическую связь позднего гидротермального пирита зон разломов с процессом формирования орогенных золоторудных месторождений, которые имеют весь этот набор минералов плюс сульфосоли (Гамянин, 2001; Горячев, 2003). Но, в отличие от представлений Л. В. Фирсова (1963), наши исследования показывают самостоятельность данной группы сульфидов, не связанных с конкретными рудными телами и околорудными метасоматитами.

Особо следует остановиться на пирротине. По нашим наблюдениям, он развит не так широко, как показано Л. И. Измайловым (1976), и накладывается на ранние глобулярный и конкреционный пириты. То есть он является постдиагенетическим и, вероятно, его возникновение отражает начало орогенного этапа регионального метаморфического преобразования осадочных пород, как считали (Измайлов, 1976; Бабкин и др., 2001). В позднюю фазу такого преобразования по пирротину местами сначала развивается марказит, а затем формируются КК и МК кристаллы метаморфогенного пирита. К сожалению, определить взаимоотношения метаморфогенного пирита с гидротермальным весьма сложно, но, тем не менее, их можно различать по проявлению полосчатой, вероятно, унаследованной зональности в гидротермальнометаморфогенном пирите, не характерной для рудно-гидротермального пирита. В редких случаях можно наблюдать реликтоподобные выделения раннего метаморфогенного пирита в массе более позднего рудно-гидротермального (рис. 11), содержащего микровключения галенита в краевой части выделений.

Таким образом, изложенные материалы позволяют принять следующую последовательность формирования выявленных разновидностей пирита: (1) ранние глобулярный и (2) конкреционный пириты, затем (3) МК и КК гидротермальнометаморфогенные пириты, иногда в ассоциации с халькопиритом и пирротином (включения), и (4) самый поздний МК и КК рудно-гидротермальный пирит в ассоциации с галенитом, сфалеритом и другими рудными минералами.

Здесь следует отметить ранее установленный Л. И. Измайловым (1976) факт, что интенсивность проявления сульфидизации увеличивается с глубиной, на примере глубоких (до 500 м) скважин, пробуренных в долине р. Мальдяк в зоне влияния Дебинского разлома. Им, в частности, показано существенное увеличение количества пирротина, начиная с глубин 160 190 м, что обусловливает высокую намагниченность пород до самого забоя скважин. Такое увеличение доли пирротина как индикатора степени 

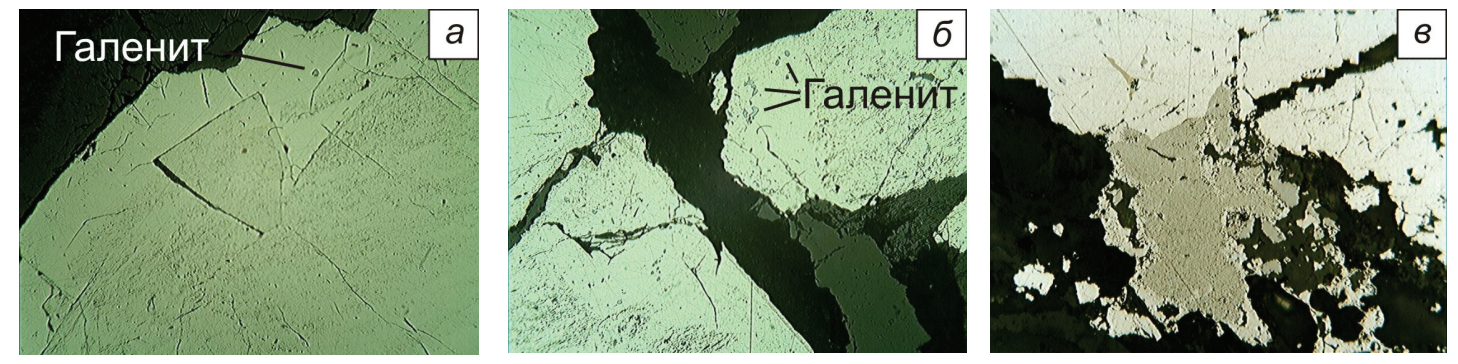

Puc. 11. Развитие рудно-гидротермального пирита с включениями галенита по метаморфогенному МК пириту в крупных кристаллах пирита из зоны Среднеканского разлома (обр. 160-гр-19) (a, б); пирротинизация раннего пылеватого пирита и развитие по пирротину позднего МК пирита, руч. Матросова (обр. 2023), участок «Дебинский» (в) (оптический микроскоп, ув. 100)

Fig. 11. Development of ore-hydrothermal pyrite with galena inclusions on metamorphogenic MK pyrite in large pyrite crystals from the Srednekan fault zone (Sample 160-гр-19) ( and on-pyrrhotine development of late MK pyrite, Matrosov Creek (Sample 2023), Debin site (в) (optical microscope, magn. 100)

метаморфизма свидетельствует об увеличении интенсивности метаморфических преобразований с глубиной, что в целом отвечает идее о плутоно-метаморфическом орогенном вале в осевой части Яно-Колымского орогена (Горячев, 2003). Возможно, именно этим обусловлена и более высокая железистость сфалерита (большие температуры образования) зоны Дебинского разлома, локализованного в осевой части такого вала. Однако в общем случае в проблеме пирротина нельзя исключать еще и наложение его более поздней генерации в связи процессами контактового метаморфизма (Измайлов, 1976; Тюкова, Ворошин, 2007).

В целом же наши наблюдения, а также известные литературные данные показывают тесную сопряженность ареалов сульфидной минерализации с зонами крупных разломов; особенно это касается позднего рудно-гидротермального пирита. Отмеченный факт увеличения интенсивности сульфидизации с глубиной, наряду с установленной последовательностью формирования генераций пирита разного происхождения, позволяет предполагать его позднюю генерацию реликтом существования региональных флюидных потоков, структурированных зонами крупных разломов. Во многих исследованиях крупных орогенных поясов уже давно ставится вопрос о существовании таких региональных флюидных потоков, структурированных крупными разломами и обеспечивающих проявления зонального метаморфизма и минерализации (Bethke, Marshak, 1990; Craw-Koons et al., 2002; Connolly, Podladchikov, 2004; Deng et al., 2009; Beaudoin et al., 2014; Gapais et al., 2014; PerezFlores et al., 2016). Наши данные по сульфидной и прежде всего пиритовой минерализации вполне укладываются в предлагаемые модели и согласуются с моделью (Gapais et al., 2014), предполагающей двухэтапное происхождение флюида: доорогенное и орогенное с формированием в ядре складчатого пояса зоны частичного плавления и зарождения флюидных потоков. Наши во многом еще предварительные данные не противоречат такой модели, но более точно это можно будет обсуждать после проведения исследований по изотопии кислорода кварцевых жил зон разломов и характеру метаморфических и постметаморфических преобразований пород в них. Это одна из задач будущего.

\section{ЗАКЛЮЧЕНИЕ}

Таким образом, предварительное изучение зон сульфидизации крупных разломов и прилегающих осадочных комплексов выявило в них не менее шести типов пирита (главный минерал), пирротин (второстепенный минерал), галенит, сфалерит, халькопирит, минералы Со и Ni. Наши минералого-геохимические и изотопные данные позволили выделить среди них три генетические группы: (1) седиментогенный пирит (глобулярный и конкреционный), (2) гидротермально-метаморфогенный мелко- и крупнокристаллический пирит, иногда в ассоциации с халькопиритом и пирротином, и (3) самый поздний мелко- и крупнокристаллический рудно-гидротермальный пирит, в ассоциации с галенитом, сфалеритом и другими рудными минералами, который определяет рудный фон зон разломов как путей миграции орогенных рудообразующих флюидов. Наши данные хорошо согласуются с моделью (Gapais et al., 2014), предполагающей двухэтапное происхождение флюида: доорогенное и орогенное с формированием в ядре складчатого пояса зоны частичного плавления и зарождения флюидных потоков. 
Работа выполнена в рамках госбюджетной тематики СВКНИИ ДВО РАН и частично в рамках проекта 18-2-001 Программы «Дальний Восток» и проекта РФФИ-а 18-45-140040.

\section{ЛИТЕРАТУРА}

Астафьева М. М., Розанов А. Ю., Хувер Р. Фрамбоиды: их структура и происхождение // Палеонтологический журнал. 2005. № 5. С. 1-7.

Бабкин П. В., Гельман М. Л., Вельдяксов Ф. Ф., Павлюченко Л. А. Перспективы выявления золотого оруденения в зонах сульфидизации в черносланцевых толщах Северо-Востока СССР // Колыма. 2001. № 2. C. 14-22.

Гамянин Г. Н., Горячев Н. А. Изотопно-геохимические исследования золоторудно-магматических систем // Магматизм и метаморфизм СевероВостока Азии : Материалы IV регион. петрограф. совещ. по Северо-Востоку России (Магадан, 46 апр. 2000 г.). Магадан : СВКНИИ ДВО РАН, 2000. C. $136-140$.

Гамянин Г. Н., Горячев Н. А., Бортников Н. С., Аникина Е. Ю. Изотопы серы в познании генезиса рудномагматических систем Северо-Востока Азии // Геодинамика, магматизм и минерагения континентальных окраин Севера Пацифики : в 3-х т. : Материалы Всеpoc. совещ., посвящ. 90-летию акад. Н. А. Шило (XII годичное собрание Сев.-Вост. отд-ния ВМО), Магадан, 3-6 июня 2003 г. Магадан : СВКНИИ ДВО РАН, 2003. T. 2. C. 207-211.

Гамянин Г. Н. Минералого-генетические аспекты золотого оруденения Верхояно-Колымских мезозоид. M. : Геос, 2001. 222 c.

Геодинамика, магматизм и металлогения Востока России / ред. А. И. Ханчук. Владивосток : Дальнаука, 2006 (кн. 1 - 1-572 с., кн. 2 - 573-982 с.)

Горячев Н. А., Пальмский Б. Ф., Петров А. Н., Хасанов И. М. Ансамбли разломов Охотско-Колымского региона // Вестник СВНЦ ДВО РАН. 2016. № 1. C. 3-15.

Горячев Н. А. Геология мезозойских золото-кварцевых жильных поясов Северо-Востока Азии. Магадан : СВКНИИ ДВО РАН, 1998. 210 с.

Горячев Н. А. Происхождение мезозойских золотокварцевых жильных поясов Северного Пацифика. Магадан : СВКНИИ ДВО РАН, 2003. 143 с.

Государственная геологическая карта Российской Федерации. Масштаб 1:1 000000 (третье поколение). Сер. Верхне-Колымская, лист Р-56 - Сеймчан / В. М. Кузнецов, С. В. Жигалин. СПб., 2008.

Гусев Г. С. Складчатые структуры и разломы Верхояно-Колымской системы мезозоид. М. : Наука, 1979. $208 \mathrm{c}$.

Измайлов Л. И. Пирротиновая минерализация металлоносных зон бассейна р. Колымы. Новосибирск : Наука, 1976, 120 с.

Крутоус М. П. Низкотемпературный метаморфизм рудовмещающих толщ и методика его изу-чения в золотоносных районах Северо-Востока СССР при геологическом картировании масштаба 1:50 000 // Метаморфические комплексы Северо-Востока СССР, их рудоносность и геологическое картирование. Магадан : СВКНИИ ДВО АН СССР, 1991. С. 124-143.

Оксман В. С. Тектоника коллизионного пояса Черского (Северо-Восток Азии). М. : ГЕОС, 2000. 269 с.

Парфенов Л. М. Континентальные окраины и островные дуги мезозоид Северо-Востока Азии. Новосибирск : Наука, 1984. 192 с.

Парфенов Л. М., Берзин Н. А., Ханчук А. И., Бадарч Г., Беличенко В. Г., Булгатов А. Н., Дриль С. И., Кириллова Г. Л., Кузьмин М. И., Ноклеберг У., Прокопьев А. В., Тимофеев В. Ф., Томуртогоо О., Янь Х. Модель формирования орогенных поясов Центральной и Северо-Восточной Азии // Тихоокеан. геология. 2003. T. 22, № 6. С. 7-41.

Парфенов Л. М., Кузьмин М. И. Тектоника, геодинамика и металлогения территории Республики Саха (Якутия) / ред. Л. М. Парфенов, М. И. Кузьмин. М. : МАИК. Наука // Интерпериодика. 2001. $571 \mathrm{c}$.

Cидоров A. A. Рудные формации и эволюционноисторический анализ благороднометалльного оруденения. Магадан : СВКНИИ ДВО РАН, 1998. 246 с.

Тюкова Е. Э., Ворошин С. В. Состав и парагенезисы арсенопирита в месторождениях и вмещающих породах Верхне-Колымского региона (к интерпретации генезиса сульфидных ассоциаций). Магадан : СВКНИИ ДВО РАН, 2007. 107 с.

Фирсов Л. В. Источники и особенности шлихового пирита в Яно-Колымском золотоносном поясе // Формирование рельефа, рыхлых отложений и россыпей Северо-Востока СССР. 1963. Сб. 1. С. 107-123 (Тр. СВКНИИ ; вып. 3).

Фор Г. Основы изотопной геологии. М. : Мир, 1989. $590 \mathrm{c}$.

Фридовский В. Ю., Полуфунтикова Л. И., Кудрин $M$. $B$. Вкрапленная сульфидная минерализация ЧайЮрьинского разлома, Верхояно-Колымская складчатая область // Вопросы геологии и комплексного освоения природных ресурсов Восточной Азии / Пятая Bсерос. науч. конф. с междунар. участием : сб. докл. Благовещенск : ИГиП ДВО РАН, 2018. Т. 1. С. $154-157$.

Хефс Й. Геохимия стабильных изотопов. М. : Мир, 1983. $200 \mathrm{c}$.

Чехов А. Д. Тектоническая эволюция СевероВостока Азии. М. : Науч. мир, 2000. 204 с.

Beaudoin N., Bellahsen N., Lacombe O., Laurent E., Pironon J. Crustal-scale fluid flow during the tectonic evolution of the Bighorn Basin (Wyoming, USA) // Basin Research. 2014. 26. 403-435. DOI: 10.1111/bre. 12032

Berner R. A. Sedimentary pyrite formation: An update // Geochimica et Cosmochimica Acta. 1984. Vol. 48. Iss. 4. P. 605-615.

Bethke C. M., Marshak S. Brine migrations across North America - the plate tectonics of groundwater // Annu. Rev. Earth Planet. Sci. 1990. Vol. 18. P. 287-315.

Connolly J. A. D., Podladchikov Y. Y. Fluid flow in compressive tectonic settings: Implications for midcrustal seismic reflectors and downward fluid migration // Journal of Geophysical Research. 2004. Vol. 109. B04201. DOI: 10.1029/2003JB002822, 2004 
Craw D., Koons P. O., Horton T., Chamberlain C. $P$. Tectonically driven fluid flow and gold mineralisation in active collisional orogenic belts: Comparison between New Zealand and western Hima laya // Tectonophysics. 2002. Vol. 348. P. 135-153. DOI: $10.1016 / \mathrm{S} 0040-1951(01) 00253-0$

Deng J., Yang L., Gao B., Sun Zh., Guo Ch., Wang $Q$., Wang J. Fluid evolution and metallogenic dynamics during tectonic regime transition: Example from the Jiapigou gold belt in Northeast China // Resource Geology. 2009. Vol. 59, No. 2. P. 140-152. DOI: 10.1111/ j.17513928.2009.00086.x

Gapais D., Jaguin J., Cagnard F., Boulvais Ph. Popdown tectonics, fluid channeling and ore deposits within ancient hot orogens // Tectonophysics. 2014. Vol. 618. P. 102-106.

Goryachev N. A., Yakubchuk A. S., Litvinenko I. S., Lozhkin A. V., Pruss Yu. V., Smirnov V. N. Giant placers of the Upper Kolyma gold fields, Yana-Kolyma province, Russian Northeast // Society of Economic Geologists, Inc. SEG Special Publications. 2020. Chapter XX (In Press).

Nokleberg W. J., Bundtzen T. K., Eremin R. A., Ratkin V. V., Dawson K. M., Shpikerman V. I., Goryachev N. A., Byalobzhesky S. G., Frolov Yu. F., Khanchuk A. I., Koch R. D., Monger J. W. H., Pozdeev A. I., Rozenblum I. S., Rodionov S. M., Parfenov L. M., Scotese C. R., Sidorov A. A. Metallogenesis and tectonics of the Russian Far East, Alaska, and the Canadian Cordillera / USGS Prof. Paper 1697. 2005. 397 p.

Pérez-Flores P., Cembrano J., Sánchez-Alfaro P., Veloso E., Arancibia G., Roquer T. Tectonics, magmatism and paleo-fluid distribution in a strike-slip setting: Insights from the northern termination of the Liquiñe - Ofqui fault system, Chile // Tectonophysics. 2016. Vol. 680. P. 192-210.

Поступила в редакиию 20.12.2019 2.

Поступила с доработки 09.01.2020 2.

\title{
ON SULFIDE MINERALIZATION OF LARGE FAULT ZONES IN THE YANA-KOLYMA OROGENIC BELT
}

\author{
N. A. Goryachev ${ }^{1}$, O. T. Sotskaya ${ }^{1}$, A. V. Ignatyev ${ }^{2}$, T. I. Velivetskaya ${ }^{2}$, E. M. Goryacheva ${ }^{1}$, \\ F. I. Semyshev ${ }^{I}$, N. V. Berdnikov ${ }^{3}$, M. A. Malinovsky ${ }^{1}$, A.V. Al'shevsky ${ }^{I}$ \\ ${ }^{I}$ North-East Interdisciplinary Scientific Research Institute n. a. N. A. Shilo, FEB RAS, Magadan \\ ${ }^{2}$ Far East Geological Institute, FEB RAS, Vladivostok \\ ${ }^{3} Y$ Y . A. Kosygin Institute of Tectonics and Geophysics, FEB RAS, Khabarovsk
}

Studying dispersed sulfidization zones of the Chay-Yurya, Debin, and Orotukan-Srednekan large faults and the adjacent Late Triassic and Early Jurassic sedimentary complexes in the southeastern flank of the Yana-Kolyma orogenic belt resulted in identifying no less than six types of pyrite (major mineral), pyrrhotine (minor mineral), galena, sphalerite, chalcopyrite, Co and $\mathrm{Ni}$ minerals. All finds of such variety of sulfide minerals are typical only for sulfidization zones in the immediate vicinity of tectonic sutures. Researching variations of mineral composition, admixture distribution, and sulfur isotopy permitted to distinguish three genetic groups of pyrite: (1) sedimentogenic pyrite (globular and concretional), (2) hydrothermal-metamorphogenics fine- and large-crystalline pyrite, sometimes in association with chalcopyrite and pyrrhotine, and (3) the latest fine- and large-crystalline ore-hydrothermal pyrite in association with galena, sphalerite, and other ore minerals, which determines the ore background of fault zones as the ways for orogenic ore-forming fluids migration. For sulfidization zones, higher contents of $\mathrm{As}, \mathrm{Ag}, \mathrm{Sb}, \mathrm{Ni}, \mathrm{Co}, \mathrm{Pb}, \mathrm{Cu}, \mathrm{Zn}$ are marked in individual samples, which is determined by pyrite and pyrrhotine typochemism and by the presence of their minerals. The first data on the concentration level of the platinum group elements in later pyrites are presented. Our data are well correlated with the model (Gapais et al., 2014) that implies the two-stage pre-orogenic and orogenic origin of the fluid, with the zone of partial melting and fluid flow generation in the core of the folding belt.

Keywords: sulfides, pyrite typomorphism, precious metals, isotope-geochemical research, sulfide impregnation zones, regional faults, southeastern flank of the Yana-Kolyma orogenic belt, North-East of Russia. 


\section{REFERENCES}

Astafyeva, M. M.; Rozanov, A. Yu.; Hoover, R., 2005, Framboids: Their Structure and Origin, Paleonthological Journal, 5, 1-7 [In Russian].

Babkin, P. V.; Gelman, M. L.; Veldyaksov, F. F., Pavlyuchenko, L. A., 2001, Perspectives for Identifying Gold Mineralization in Sulfidization Zones in Black Slate Masses of the USSR North-East, Kolyma, 2, 14-22 [In Russian].

Beaudoin, N.; Bellahsen, N.; Lacombe, O.; Laurent, E.; Pironon, J., 2014, Crustal-scale fluid flow during the tectonic evolution of the Bighorn Basin (Wyoming, USA), Basin Research, 26, 403-435, DOI: 10.1111/bre.12032

Berner, R. A., 1984, Sedimentary Pyrite Formation: An Update, Geochemica et Cosmochimica Acta, 48, 4, 605-615.

Bethke, C. M.; Marshak, S., 1990, Brine Migrations across North America - the Plate Tectonics of Groundwater, Annu. Rev. Earth Planet. Sci., 18, 287-315.

Chekhov, A. D., 2000, Tectonic Evolution of the NorthEast of Asia, Moscow, Nauchny Mir [In Russian].

Connolly, J. A. D.; Podladchikov, Y. Y., 2004, Fluid Flow in Compressive Tectonic Settings: Implications for Midcrustal Seismic Reflectors and Downward Fluid Migration, Journal of Geophysical Research, 109, B04201, DOI: $10.1029 / 2003 J B 002822$

Craw, D.; Koons, P. O.; Horton, T.; Chamberlain, C. P., 2002, Tectonically Driven Fluid Flow and Gold Mineralisation in Active Collisional Orogenic Belts: Comparison between New Zealand and Western Himalaya, Tectonophysics, 348, 1-3, 15, 135-153, DOI: org/10.1016/S0040-1951(01)00253-0

Deng, J.; Yang, L.; Gao, B.; Sun, Zh.; Guo, Ch.; Wang, Q.; Wang, J., 2009, Fluid Evolution and Metallogenic Dynamics during Tectonic Regime Transition: Example from the Jiapigou Gold Belt in Northeast China, Resource Geology, 59, 2, 140-152, DOI: 10.1111/j.17513928.2009.00086.x

Faure, G., 1989, Principles of Isotope Geology, Moscow, Mir [In Russian].

Firsov, L. V., 1963, Sources and Features of Pan Pyrite in the Yana-Kolyma Gold-Bearing Belt, Formation of Relief, Soft Deposits, and Placers in the North-East of the USSR, Vol. 1, 107-123 (Trudy SVKNII, 3) [In Russian].

Fridovsky, L. V.; Polufuntikova, L. I.; Kudrin, M. V., 2018, Impregnated Sulfide Mineralization of the ChayYurya Fault, Verkhoyansk-Kolyma Folded Area, Issues of Geology and Interdisciplinary Exploration of Natural Resources in East Asia, $5^{\text {th }}$ All-Russia Conference with International Participation, Book of Reports, Blagoveshchensk, IGNM FEB RAS, 1, 154-157 [In Russian].

Gamyanin, G. N., 2001, Mineralogical and Genetic Aspects of Gold Mineralization of the VerkhoyanskKolyma Mesozoids, Moscow, Geos [In Russian].

Gamyanin, G. N.; Goryachev, N. A., 2000, IsotopeGeochemical Research of Gold Ore-Magmatic Systems, Magmatism and Metamorphism of the North-East of Asia, Materials of $4^{\text {th }}$ Regional Petrographic Meeting on Russia's North-East, Magadan, April 4-6, 2000, Magadan, NEISRI FEB RAS, 136-140 [In Russian].
Gamyanin, G. N.; Goryachev, N. A.; Bortnikov, N. S.; Anikina, Ye. Yu., 2003, Sulfur Isotopes in Cognition of Northeast Asia's Ore-Magmatic Systems Genesis, Geodynamics, Magmatism, and Minerageny of the North Pacific Continental Margins, Materials of All-Russia Meeting Devoted to the $90^{\text {th }}$ Anniversary of Academician N. A. Shilo, $12^{\text {th }}$ Annual Meeting of the North-East Branch of the Russian Mineralogical Society, Magadan, June 3-6, 2003, Magadan, NEISRI FEB RAS, 2, 207-211 [In Russian].

Gapais, D.; Jaguin, J.; Cagnard, F.; Boulvais, Ph., 2014, Pop-down Tectonics, Fluid Channeling and Ore Deposits within Ancient Hot Orogens, Tectonophysics, Elsevier, 618, 102-106.

Geodynamics, Magmatism, and Metallogeny of Russia's East, Ed. A. I. Khanchuk, Vladivostok, Dalnauka, Book 1, 1-572, Book 2, 573-982 [In Russian].

Goryachev, N. A., 1998, Geology of Mesozoic GoldQuartz Lode Belts of Northeast Asia, Magadan, NEISRI FEB RAS [In Russian].

Goryachev, N. A., 2003, Origin of Mesozoic GoldQuartz Lode Belts of the North Pacific, Magadan, NEISRI FEB RAS [In Russian].

Goryachev, N. A.; Palymsky, B. F.; Petrov, A. N.; Khasanov, I. M., 2016, Fault Ensembles in the Okhotsk-Kolyma Region, Vestnik NESC FEB RAS, 1, 3-15 [In Russian].

Goryachev, N. A.; Yakubchuk, A. S.; Litvinenko, I. S.; Lozhkin, A. V.; Pruss, Yu. V.; Smirnov, V. N., 2020, Giant Placers of the Upper Kolyma Gold Fields, Yana-Kolyma Province, Russian Northeast, Society of Economic Geo-logists, Inc. SEG Special Publications, Chapter XX (In Press).

Gusev, G. S., 1979, Folded Structures and Faults of the Verkhoyansk-Kolyma Mesozoid System, Moscow, Nauka [In Russian].

Hoefs, J., 1983, Stable Isotope Geochemistry, Moscow, Mir [In Russian].

Izmaylov, L. I., 1976, Pyrrhotine Mineralization of Metal-Bearing Zones in the Kolyma River Basin, Novosibirsk, Nauka [In Russian]

Krutous, M. P., 1991, Low-Temperature Metamorphism of Ore-Hosting Masses and the Methodology for Studying It in Gold-Bearing Districts of the USSR North-East with 1:50 000 Geological Mapping, Metamorphic Complexes in the USSR North-East, Their Ore Bearing, and Geological Mapping, Magadan, NEISRI FEB RAS, 124-143 [In Russian].

Nokleberg, W. J.; Bundtzen, T. K.; Eremin, R. A.; Ratkin, V. V.; Dawson, K. M.; Shpikerman, V. I.; Goryachev, N. A.; Byalobzhesky, S. G.; Frolov, Yu. F.; Khanchuk, A. I.; Koch, R. D.; Monger, J. W. H.; Pozdeev, A. I.; Rozenblum, I. S.; Rodionov, S. M.; Parfenov, L. M.; Scotese, C. R.; Sidorov, A. A., 2005, Metallogenesis and Tectonics of the Russian Far East, Alaska, and the Canadian Cordillera, USGS Prof. Paper 1697.

Oksman, V. S., 2000, Tectonics of the Chersky Collisional Belt, North-East of Asia, Moscow, GEOS [In Russian].

Parfenov, L. M., 1984, Continental Margins and Island Arcs of Northeast Asia's Mesozoids, Novosibirsk, Nauka [In Russian]. 
Parfenov, L. M.; Berzin, N. A.; Khanchuk, A. I.; Badarch, G.; Belichenko, V. G.; Bulgatov, A. N.; Dril, S. I.; Kirillova, G. L.; Kuzmin, M. I.; Nockleberg, W.; Prokopyev, A. V.; Timofeyev, V. F.; Tomurtogoo, O.; Yan, H., 2003, Model of Forming Orogenic Belts in Central and Northeast Asia, Tikhookeanskaya Geologiya, 22, 6, 7-41 [In Russian].

Parfenov, L. M.; Kuzmin, M. I., 2001, Tectonics, Geodynamics, and Metallogeny of the Territory of the Sakha Republic (Yakutia), Eds. L. M. Parfenov, M. I. Kuzmin, Moscow, MAIK, Nauka, Interperiodika [In Russian].

Pérez-Flores, P.; Cembrano, J.; Sánchez-Alfaro, P.; Veloso, E.; Arancibia, G.; Roquer, T., 2016, Tectonics, Magmatism and Paleo-Fluid Distribution in a Strike-
Slip Setting: Insights from the Northern Termination of the Liquiñe - Ofqui Fault System, Chile, Tectonophysics, 680, 192-210.

Sidorov, A. A., 1998, Ore Formations and Evolutionary Historic Analysis of Precious Metal Mineralization, Magadan, NEISRI FEB RAS [In Russian].

State Geological Map of the Russian Federation, Scale 1:1 $000000,3^{\text {rd }}$ Generation, Series Upper Kolyma, Sheet P-56-Seimchan, V. M. Kuznetsov, S. V. Zhigalin, St. Petersburg [In Russian].

Tyukova, Ye. E.; Voroshin, S. V., 2007, Composition and Parageneses of Arsenopyrite in Deposits and Host Rocks of the Upper Kolyma Region (for Interpreting Genesis of Sulfide Associations), Magadan, NEISRI FEB RAS [In Russian]. 